\title{
The Photosystem II Oxygen-Evolving Complex Protein PsbP Interacts With the Coat Protein of Alfalfa mosaic virus and Inhibits Virus Replication
}

\author{
Muthukumar Balasubramaniam, ${ }^{1}$ Bong-Suk Kim, ${ }^{1}$ Heather M. Hutchens-Williams, ${ }^{1,2}$ and \\ L. Sue Loesch-Fries ${ }^{1}$
}

${ }^{1}$ Department of Botany and Plant Pathology, Purdue University, West Lafayette, IN 47907, U.S.A.; ${ }^{2}$ North Carolina Department of Agriculture \& Consumer Services, Raleigh, NC, U.S.A.

Submitted 9 February 2014. Accepted 11 June 2014.

\begin{abstract}
Alfalfa mosaic virus (AMV) coat protein (CP) is essential for many steps in virus replication from early infection to encapsidation. However, the identity and functional relevance of cellular factors that interact with $C P$ remain unknown. In an unbiased yeast two-hybrid screen for CPinteracting Arabidopsis proteins, we identified several novel protein interactions that could potentially modulate AMV replication. In this report, we focus on one of the novel $\mathrm{CP}$ binding partners, the Arabidopsis PsbP protein, which is a nuclear-encoded component of the oxygen-evolving complex of photosystem II. We validated the protein interaction in vitro with pull-down assays, in planta with bimolecular fluorescence complementation assays, and during virus infection by co-immunoprecipitations. CP interacted with the chloroplast-targeted PsbP in the cytosol and mutations that prevented the dimerization of $\mathrm{CP}$ abolished this interaction. Importantly, PsbP overexpression markedly reduced virus accumulation in infected leaves. Taken together, our findings demonstrate that AMV CP dimers interact with the chloroplast protein PsbP, suggesting a potential sequestration strategy that may preempt the generation of any PsbP-mediated antiviral state.
\end{abstract}

As obligate intracellular parasites, viruses foster and maintain an intimate relationship with their hosts during infection. Viral genomes typically encode very little genetic information and, hence, viruses usurp many of the host cell functions to complete a productive systemic infection cycle. Recent studies have demonstrated the requirement for specific host factors at every step of plant virus infection, including replication (Huang et al. 2012; Ivanov and Makinen 2012; Mine and Okuno 2012) and virus movement (Liu and Nelson 2013; Pena et al. 2012; Tilsner and Oparka 2012). Conversely, an increasing number of host factors that negatively affect virus accumulation have been identified (Ahlquist et al. 2003; Bhat et al. 2013; Cho et al. 2012; Ishibashi et al. 2009; Love et al. 2012;

M. Balasubramaniam and B.-S. Kim contributed equally to this work.

Corresponding author: L. S. Loesch-Fries; Telephone: +1.765.494.4624; Fax: +1.765.494.0363; E-mail: loeschfr@purdue.edu

* The $\boldsymbol{e}$-Xtra logo stands for "electronic extra" and indicates that a supplementary table is published online and that Figures 3, 4, 5, and 6 appear in color online.

(C) 2014 The American Phytopathological Society
Manfre et al. 2011; Nagy and Pogany 2010; Wang et al. 2009c). It is likely that many of these host proteins are involved in innate defense pathways that confer resistance in the host (Padmanabhan and Dinesh-Kumar 2010; Zvereva and Pooggin 2012).

Alfalfa mosaic virus (AMV) is the single species in the Alfamovirus genus in the Bromoviridae family. In total, 600 plant species belonging to 70 families are susceptible to AMV infection (Bol 2003), which induces a variety of symptoms, including bright yellow mosaic and chlorotic lesions (Jaspars and Bos 1980), both of which are evidence of damage to chloroplasts. The three genomic positive-sense RNA molecules of AMV are separately encapsidated into bacilliform particles and encode four proteins: RNA1 encodes the P1 protein, which contains a putative methyltransferase motif at the $\mathrm{N}$ terminus and a putative helicase motif at the C terminus; RNA2 encodes the $\mathrm{P} 2$ protein that harbors a putative polymerase motif; and RNA3 encodes the movement protein (MP) and the coat protein $(\mathrm{CP})$, which is translated from the subgenomic RNA4 synthesized during RNA3 replication.

Unlike most other positive-sense RNA viruses, the genomic RNA molecules of AMV can initiate an infection only when supplemented with CP or RNA4. Such CP-dependent genome activation is also exhibited by the ilarviruses, which have a genome organization similar to that of AMV (Bol 1999). In all four AMV RNAs, 145 nucleotides at the $3^{\prime}$ ends of all four AMV RNAs are homologous and function as CP-binding sites (Bol 2003). Many studies have defined the CP-binding site and the RNA sequence critical for CP-RNA interaction, as well as validated the importance of this interaction in AMV infection (Ansel-McKinney et al. 1996; Baer et al. 1994; Guogas et al. 2004; Houser-Scott et al. 1994; Reusken et al. 1994). The biological significance of the interaction remains unresolved (Chen and Olsthoorn 2010; Houwing and Jaspars 2000; Petrillo et al. 2005); however, several models seek to explain the role of AMV CP in genome activation. The messenger release model proposes that $\mathrm{CP}$ must bind to newly synthesized genomic RNA to release it from replication complexes (Houwing and Jaspars 2000; Jaspars 1999; Jaspars and Houwing 2002). The conformational switch model proposes that $\mathrm{CP}$ binding extends a pseudoknot in the $3^{\prime}$ terminus of the viral RNA, thereby promoting a switch from replication to translation (Chen and Olsthoorn 2010; Krab et al. 2005; Neeleman et al. 2001). The $3^{\prime}$ organization model proposes that CP binding compacts the viral RNA, thereby facilitating RNA-replicase interactions and stimulating viral RNA replication (Guogas et al. 2004; Petrillo et al. 2005; Reichert et al. 2007; Simon and Gehrke 2009). 
Perhaps these models are not mutually exclusive; AMV CP could have many functions in the virus life cycle, as do other virus capsid proteins (Ni and Kao 2013; Willows et al. 2013).

Compared with the considerable information available on AMV biology, knowledge about AMV-host interactions, including those involving $\mathrm{CP}$, is scant. This knowledge gap significantly limits further understanding of AMV biology and the rational development of preventive and antiviral strategies to curb the considerable economic costs incurred from AMV and ilarvirus infection (Bailiss and Ollennu 1986; Jones 2012; Pallas et al. 2012). Recent advances in high-throughput genomic, transcriptomic, and proteomic approaches have spurned substantial interest and rapid progress in deciphering virus-host interactions. However, the lack of a genetically tractable host system complicated efforts to identify host factors involved in AMV infection. To address that bottleneck, we previously established the AMV-Arabidopsis pathosystem (Balasubramaniam et al. 2006), which opens up opportunities to study virus-host interactions by using forward and reverse genetic approaches.

In this study, we sought to identify Arabidopsis proteins that interact with AMV proteins by using a yeast two-hybrid $(\mathrm{Y} 2 \mathrm{H})$ assay that detects protein interactions in the cytoplasm. Here, we report the successful identification of novel and specific interactions between AMV CP and a number of Arabidopsis proteins and present a detailed characterization of the protein interaction between $\mathrm{CP}$ and the PsbP protein, which is part of the oxygen-evolving complex (OEC) of photosystem II (PSII). The CP-PsbP interaction was confirmed in vitro by a pull-down assay, in planta by bimolecular fluorescence complementation (BiFC), and in AMV-infected plant tissues by immunoprecipitation. We further determined that dimerization of $\mathrm{CP}$, which results in the functional unit in vivo, is required for interaction with PsbP and that PsbP overexpression negatively modulates AMV replication. Taken together, our findings strongly suggest a functional role for $\mathrm{CP}-\mathrm{PsbP}$ interaction in AMV infection.

\section{RESULTS}

\section{Y2H assays reveal AMV CP-interacting Arabidopsis proteins.}

The SOS Recruitment System Y2H (SRS.Y2H) assay (Aronheim et al. 1997) was selected because it detects proteinprotein interactions in the cytoplasm, which is the native site of AMV replication. Interaction of bait and prey proteins at the plasma membrane of temperature-sensitive yeast cells reconstitute the RAS signaling pathway, thereby allowing colonies to grow at $37^{\circ} \mathrm{C}$ (Aronheim et al. 1994). Before initiating the SRS.Y2H library screening, we tested the suitability of AMV $\mathrm{CP}$ as bait in the SRS.Y2H system. Enzyme-linked immunosorbent assay with $\mathrm{CP}$-specific antibodies confirmed robust expression of the hSos-CP fusion protein from the pSos- $\mathrm{CP}$ plasmid in yeast cells (data not shown). The cdc $25 \mathrm{H}$ cells harboring pSos-CP grew at 25 but not at $37^{\circ} \mathrm{C}$ when plated on synthetic dropout (SD) medium supplemented with glucose (SD/glucose) but lacking leucine (-L) and SD supplemented with galactose (SD/galactose) (-L) (Fig. 1A). Thus, the hSos$\mathrm{CP}$ fusion protein by itself is incapable of rescuing the temperature-sensitive phenotype of mutant $\mathrm{cdc} 25 \mathrm{H}$ cells by self-activation, thereby indicating its suitability for use in the SRS.Y2H assay.

To screen the SRS.Y2H library, pSos-CP and pMyr-AtcDNA plasmids were introduced into the cdc $25 \mathrm{H}$ cells by co-transformation. Screening of the Arabidopsis SRS.Y2H library yielded 30 positive colonies on SD/galactose lacking uracil and leucine (-UL) medium at $37^{\circ} \mathrm{C}$. Two rounds of additional selections on $\mathrm{SD} /$ galactose (-UL) medium at $37^{\circ} \mathrm{C}$ further refined the number of true positive colonies to 12 , from which seven
cDNAs could be amplified and sequenced. The positive colonies displaying exclusive or enhanced growth at $37^{\circ} \mathrm{C}$ on $\mathrm{SD} /$ galactose (-UL) medium when compared with that on $\mathrm{SD} /$ glucose (-UL) medium are shown in Figure 1B. The pMyr-AtcDNA plasmids were isolated from the positive colonies and their DNA sequences determined. The identities of the seven AtcDNAs as determined by BLAST analysis with the National Center for Biotechnology Information (NCBI) database are listed in Table 1. All AtcDNAs were in frame with the myristoylation signal sequence, suggesting that the fusion proteins were expressed from all AtcDNAs. A number of the candidate protein partners have previously been implicated in plant virus replication (Kaido et al. 2007; Nagy et al. 2011; Su et al. 2010; Ueki and Citovsky 2002).

The chloroplast-resident PsbP protein encoded by AtcDNA from the Y2H colony CP-SRS-12 is of special interest because AMV and other viruses cause various chlorotic patterns on leaves due to chloroplast damage. PsbP is one of the protein components of the OEC of PSII located on the luminal side of the thylakoid membrane. It is a member of a protein family in higher plants, which includes proteins with functional roles in regulating and stabilizing the OEC and homologs with unknown functions (Ifuku et al. 2008, 2010). The protein encoded at locus At1g06680 (PsbP-1) is the only functional PsbP protein in Arabidopsis thaliana because the protein encoded at a second locus is not expressed (Bricker et al. 2013). The plasmid encoding PsbP was isolated from the yeast colony and used to transform cdc $25 \mathrm{H}$ cells along with pSos-CP. The resulting yeast colonies grew well on SD/galactose (-UL) but not on $\mathrm{SD} /$ glucose (-UL) at $37^{\circ} \mathrm{C}$ (Fig. 1C). The yeast harboring the empty plasmid vector pSos and pMyr-At1g06680, encoding PsbP, which did not grow on SD/glucose (-UL) or SD/galactose $(-\mathrm{UL})$ at $37^{\circ} \mathrm{C}$, served as the negative control. This confirmed that a specific protein-protein interaction mediated by the PsbP-encoding pMyr-At1g06680 and the CP-encoding pSos$\mathrm{CP}$ enabled the yeast growth at $37^{\circ} \mathrm{C}$.

\section{$\mathrm{CP}$ and PsbP interact in vitro.}

Glutathione-S-transferase (GST) pull-down assays were used to determine whether $\mathrm{CP}$ and PsbP interact in vitro. A recombinant GST-CP fusion protein was used as bait and ${ }^{35} \mathrm{~S}$ labeled $\mathrm{CP}$ and $\mathrm{PsbP}$ were used as potential prey partners. Magnetic particles decorated with GST-CP captured ${ }^{35} \mathrm{~S}-\mathrm{CP}$ prey, whereas those decorated with GST alone did not (Fig. 2). This indicates that GST-CP interacted with ${ }^{35} \mathrm{~S}-\mathrm{CP}$ to form $\mathrm{CP}$ dimers, which are the native state of AMV CP in solution. When ${ }^{35} \mathrm{~S}$-PsbP was provided as prey, a significant amount of ${ }^{35} \mathrm{~S}$-PsbP was captured by GST-CP, whereas a small amount was bound by GST alone (Fig. 2). The strong signal from ${ }^{35} \mathrm{~S}$ PsbP bound to GST-CP bait indicates a specific interaction, whereas the faint background signal in the GST control pulldown is not an uncommon observation (Uhr et al. 2004).

\section{$\mathrm{CP}$ and PsbP interact in planta.}

To determine whether AMV CP and PsbP interact in planta, we used the BiFC assay, in which protein-protein interaction reconstitutes yellow fluorescent protein (YFP) fragments, resulting in fluorescence. BiFC plasmid variants encoding fusion proteins tagged at the $\mathrm{N}$ terminus with the nonfluorescent $\mathrm{N}$ or C-terminal fragment of YFP were constructed for each protein of interest, including wild-type $\mathrm{CP}$, mutant $\mathrm{CP}$, and PsbP. Nomenclature of the plasmid constructs follow the convention whereby ${ }^{n} \mathrm{Y}$ refers to the $\mathrm{N}$-terminal fragment of YFP, ${ }^{\mathrm{c}} \mathrm{Y}$ refers to the C-terminal fragment of YFP, and placement of the tag name to the left of the protein name indicates that the tag is attached to the $\mathrm{N}$ terminus of the protein. To determine the suitability of our BiFC constructs for testing protein interac- 
tions, we sought to detect the dimerization of $\mathrm{CP}$, which occurs naturally in solution and in planta. The BiFC constructs were introduced into Nicotiana benthamiana by agroinfiltration and assayed for the reconstitution of fluorescent YFP. Fluorescence resulted upon the co-infiltration of $\mathrm{p}^{\mathrm{n}} \mathrm{Y}-\mathrm{CP}$ plus $\mathrm{p}^{\mathrm{c}} \mathrm{Y}-\mathrm{CP}$ but not following infiltration of $\mathrm{p}^{\mathrm{c}} \mathrm{Y}-\mathrm{CP}$ and the plasmid containing the ${ }^{n} \mathrm{Y}$ fragment of YFP (Fig. 3A). To confirm that this BiFCinduced YFP fluorescence resulted specifically from CP dimerization, additional BiFC plasmids were constructed to encode the $\mathrm{CP}$ mutants $\mathrm{CP}-\mathrm{WFP}$ or $\mathrm{CP}-\mathrm{W}$, in which alanine was sub- stituted for $\mathrm{W}_{191}, \mathrm{~F}_{197}$, and $\mathrm{P}_{198}$ or the single amino acid $\mathrm{W}_{191}$ required for $\mathrm{CP}$ dimerization, respectively (Choi and LoeschFries 1999). Following infiltration of pairs of these plasmids into $N$. benthamiana, no YFP fluorescence was detected, as shown for the expression of ${ }^{n}$ Y-CP-WFP $+{ }^{c}$ Y-CP-WFP (Fig. $3 \mathrm{~A}$ ) or for ${ }^{\mathrm{n}} \mathrm{Y}-\mathrm{CP}-\mathrm{W}+{ }^{\mathrm{C}} \mathrm{Y}-\mathrm{CP}-\mathrm{W}$ (data not shown). As expected, infiltration of $\mathrm{p}^{\mathrm{c}} \mathrm{Y}-\mathrm{CP}-\mathrm{WFP}$ alone did not result in any fluorescence (data not shown). Immunoblot analysis indicated a robust expression of fusion proteins in tissues positive for YFP fluorescence and confirmed the expression of $\mathrm{p}^{\mathrm{n}} \mathrm{Y}-\mathrm{CP}$ -

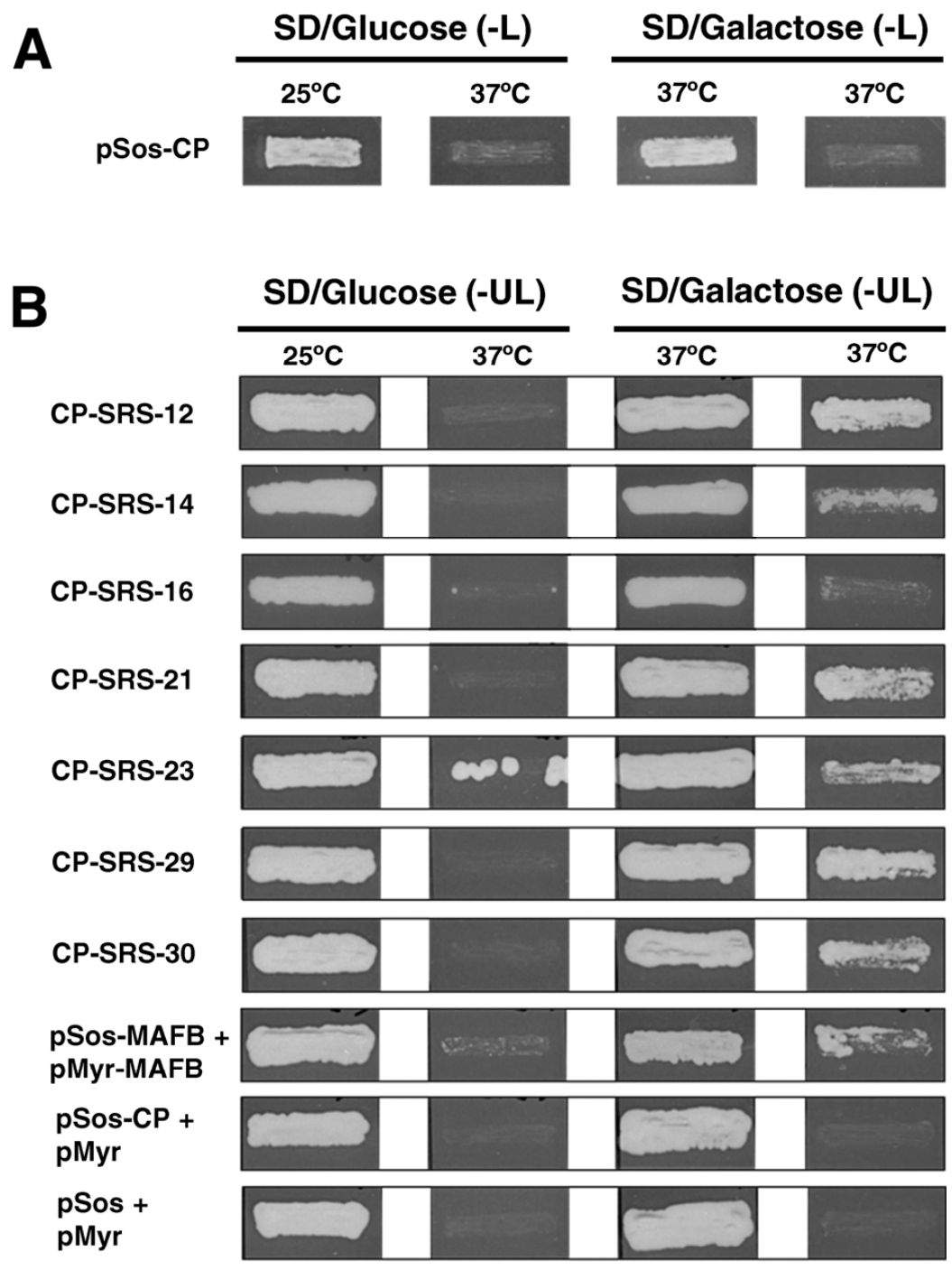

C

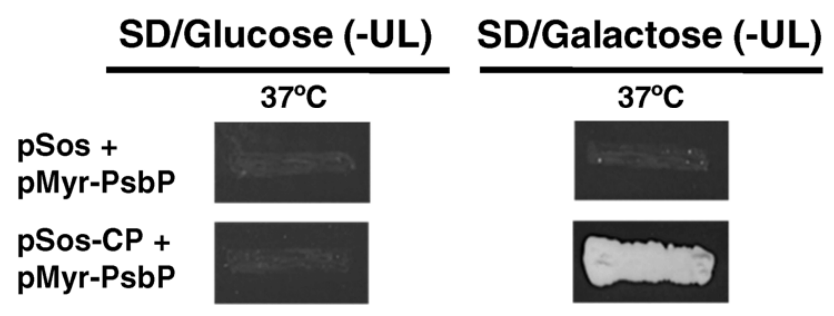

Fig. 1. Identification of Alfalfa mosaic virus (AMV) coat protein (CP)-binding host proteins by SOS recruitment system yeast two-hybrid (SRS.Y2H) assay. A, Determination of the suitability of pSos-CP as bait for the SRS.Y2H assays. Yeast harboring pSos-CP were plated on SD/glucose (-L) or SD/galactose (L) medium and incubated at the permissive temperature of $25^{\circ} \mathrm{C}$ or the restrictive temperature of $37^{\circ} \mathrm{C}$. B, Screening of the SRS.Y2H library with pSos-CP. Colonies harboring pSos-CP and pMyr-AtcDNA after two rounds of selection are shown on SD/glucose (-UL) and SD/galactose (-UL) at 25 and $37^{\circ} \mathrm{C}$. The colony number is indicated at the left. Positive (pSos-MAFB + pMyr-MAFB) and negative controls (pSos + pMyr and pSos-CP + pMyr) are shown below the colony screens. C, Retransformation assay for cDNA from colony CP-SRS-12. Yeast cells were co-transformed with pSos-CP and pMyr-PsbP plasmid isolated from the yeast colony and grown on selective media at $37^{\circ} \mathrm{C}$. Yeast harboring the pMyr-PsbP and pSos served as the negative control. 
WFP and $\mathrm{p}^{\mathrm{c} Y-C P-W F P}$ in infiltrated tissues that were not fluorescent (Fig. 3B).

$\mathrm{BiFC}$ assays to detect interaction between $\mathrm{CP}$ and PsbP resulted in reconstituted YFP fluorescence following infiltration of $\mathrm{p}^{\mathrm{c} Y-C P}$ and $\mathrm{p}^{\mathrm{n}} \mathrm{Y}-\mathrm{PsbP}$ (Fig. 4A) or $\mathrm{p}^{\mathrm{n}} \mathrm{Y}-\mathrm{CP}$ and $\mathrm{p}^{\mathrm{c}} \mathrm{Y}-\mathrm{PsbP}$ (data not shown). The BiFC-induced YFP fluorescence was detected throughout the cytosol in the epidermal cells.

\section{Dimerization of $\mathrm{CP}$ is required for interaction with PsbP.}

AMV CP dimers exist naturally in solution and are the minimal building blocks of virions (Kumar et al. 1997). They are also more efficient than $\mathrm{CP}$ monomers in genome activation, which involves early translation of the AMV genome (Choi et al. 2003; Krab et al. 2005). To determine whether CP dimerization is required for $\mathrm{CP}-\mathrm{PsbP}$ interaction, BiFC plasmids encoding ${ }^{c} \mathrm{Y}-\mathrm{CP}-\mathrm{WFP}$, which was unable to dimerize in the BiFC assay (Fig. 3A), and ${ }^{\mathrm{n}}$ Y-PsbP were infiltrated into N. benthamiana. No fluorescence was detected in this assay (Fig. 4A) or in assays testing BiFC between ${ }^{\mathrm{n}} \mathrm{Y}-\mathrm{CP}-\mathrm{WFP}$ and ${ }^{\mathrm{c}} \mathrm{Y}-\mathrm{PsbP}$ (data not shown). However, in all infiltrated tissues, the fusion proteins were expressed (Fig. 4B). BiFC assays with the CP-W mutant, which lacks the ability to dimerize due to the substitution $\mathrm{W}_{191} \mathrm{~A}$, and PsbP were also negative (data not shown). Therefore, PsbP does not interact with dimerization-defective $\mathrm{CP}$ mutants. These findings indicate that the sequences necessary for CP dimerization are also required for interaction with PsbP. The CP mutations may be involved in stacking interactions between the dimer partners (Kumar et al. 1997); therefore, perhaps, a distinct structural element forms during $\mathrm{CP}$ dimerization that serves as the binding site for PsbP.

\section{$\mathrm{CP}$ and PsbP interact during infection resulting} in the accumulation of PsbP in the cytosol.

AMV CP and PsbP interacted in $N$. benthamiana leaves when overexpressed by agroinfiltration. To determine whether the interaction occurs during virus infection, AMV-infected $N$. benthamiana leaves were analyzed by reciprocal immunoprecipitation assays. Immunoprecipitation with anti-PsbP antibody (PsbP pull-down) isolated protein complexes that con-
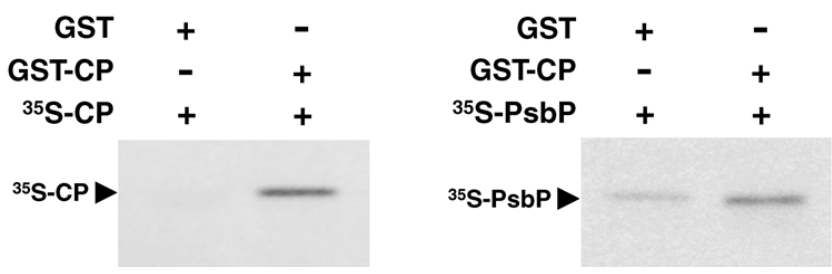

Fig. 2. Coat protein (CP)-PsbP complex formation in vitro. CP-PsbP interaction in an in vitro glutathione- $S$-transferase (GST) pull-down assay. GST or GST-CP bound to glutathione-coated magnetic particles was used to pull-down ${ }^{35} \mathrm{~S}-\mathrm{CP}$ or ${ }^{35} \mathrm{~S}-\mathrm{P}$ sbP translated in vitro. Captured proteins were analyzed in a $12 \%$ gel by sodium dodecyl sulfate polyacrylamide gel electrophoresis followed by autoradiography. Identities of the bait and prey proteins are indicated above the lanes. Identities of the protein bands are indicated at the left. tained $\mathrm{CP}$, which were detected with anti-CP monoclonal antibodies (Fig. 5A). This indicates that virus-encoded untagged $\mathrm{CP}$ interacts with endogenous $\mathrm{PsbP}$ during virus infection, when PsbP levels may be lower than during the BiFC assays. Efforts to use anti-CP antibody (CP pull-down) to isolate complexes in which PsbP could be detected were unsuccessful (data not shown). There is vigorous synthesis of $\mathrm{CP}$ during infection and only a small portion may be complexed with PsbP, whereas most of the CP resides in AMV virions. Therefore, CP pull-downs would likely contain $\mathrm{CP}$ primarily from

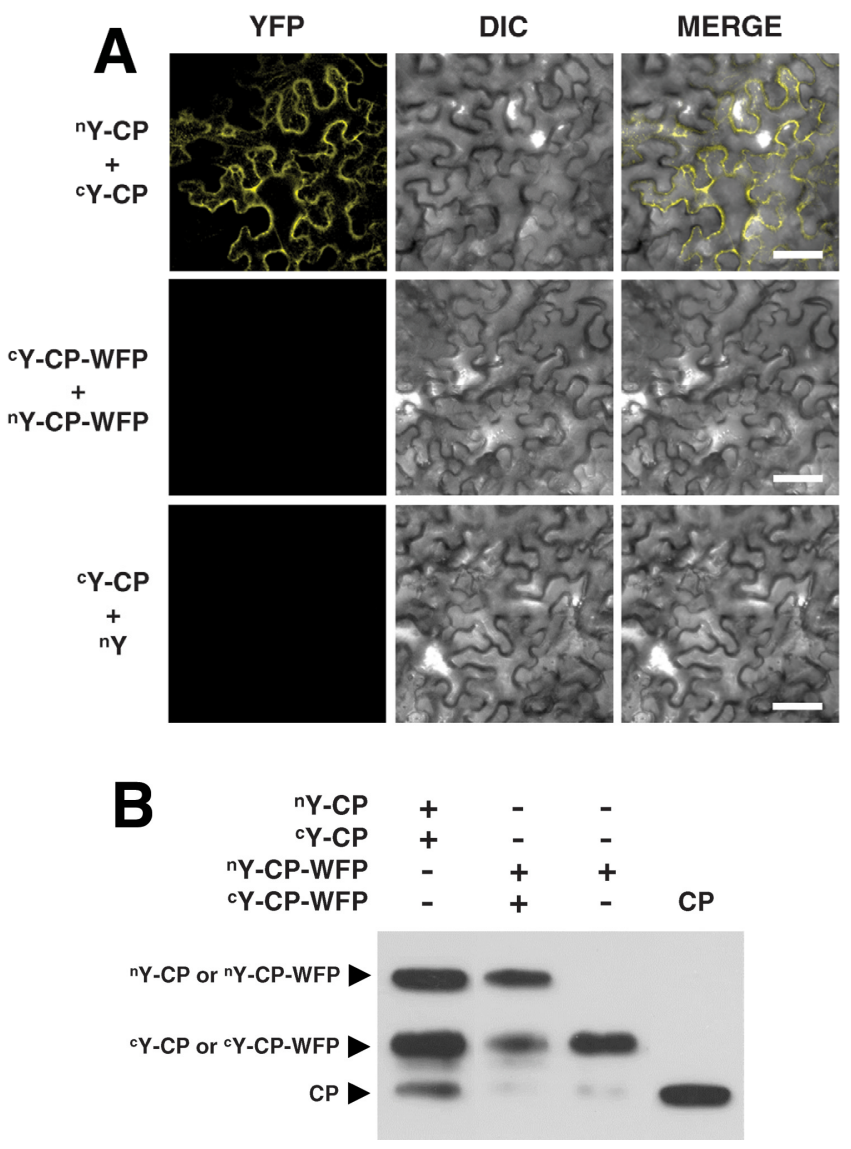

Fig. 3. Validation of the bimolecular fluorescence complementation (BiFC) assay. A, Alfalfa mosaic virus (AMV) coat protein (CP) dimerization-induced BiFC. Wild type and mutant AMV CP harboring ${ }^{\mathrm{n}} \mathrm{Y}$ or ${ }^{\mathrm{c}} \mathrm{Y}$ portions of yellow fluorescent protein (YFP) at the $\mathrm{N}$ termini were expressed by agroinfiltrating the encoding plasmids into leaves of Nicotiana benthamiana. The BiFC-induced YFP fluorescence in leaf discs from infiltrated leaves was monitored at 2 days postinfiltration by confocal microscopy. Fusion protein combinations expressed in each sample are indicated at the left of the corresponding row of images. Scale bars represent $50 \mu \mathrm{m}$. B, Accumulation of the fusion proteins in N. benthamiana. Agroinfiltrated plant tissue was assayed by immunoblot analysis with anti-CP antibody. Plasmids agroinfiltrated into each sample are indicated above the blot. The right lane contains $\mathrm{CP}$ from purified virions. Identities of the protein bands are indicated at the left.

Table 1. AtcDNAs coding for proteins that interact with Alfalfa mosaic virus coat protein identified by the SOS Recruitment System yeast two-hybrid (SRS.Y2H) screen

\begin{tabular}{|c|c|c|c|}
\hline Y2H clone & Locus ID & Annotated protein & Reference \\
\hline CP-SRS-12 & At1g06680 & Full-length PsbP protein in the oxygen-evolving complex of photosystem II & Ifuku et al. 2008 \\
\hline CP-SRS-14 & At1g16880 & C-terminal 152 amino acids of ACRII (ACT domain-containing protein) $(52 \%)^{\mathrm{a}}$ & Sung et al. 2011 \\
\hline CP-SRS-16 & At4g17150 & C-terminal 169 amino acids of $\alpha / \beta$-hydrolases superfamily protein $(42 \%)^{\mathrm{a}}$ & Marchot and Chatonnet 2012 \\
\hline CP-SRS-21 & At5g59880 & Full-length ADF3 protein (actin depolymerizing factor 3) & Maciver and Hussey 2002 \\
\hline CP-SRS-23 & At3g12390 & Full-length $\alpha$-NAC protein (nascent polypeptide associated complex $\alpha$ subunit) & Rospert et al. 2002 \\
\hline CP-SRS-29 & At3g09440 & C-terminal 181 amino acids of Hsc70-3 protein (heat shock cognate $70-k D a$ protein 3$)(28 \%)^{a}$ & Sung et al. 2001 \\
\hline CP-SRS-30 & At2g05510 & C-terminal 116 amino acids of GRP9 protein (glycine-rich protein 9) $(91 \%)^{\mathrm{a}}$ & Mangeon et al. 2010 \\
\hline
\end{tabular}

a Percentage of annotated open reading frame present in the Myr-cDNA. 
virions. These results show that AMV CP interacts with PsbP of $N$. benthamiana as well as that of Arabidopsis.

The BiFC signal resulting from the interaction between CP and PsbP was in the cytosol of epidermal cells. To determine whether CP-PsbP complexes also accumulated in the cytosol of infected cells, we investigated the distribution of PsbPgreen fluorescent protein (GFP) expressed in cells of AMVinfected $N$. benthamiana by agroinfiltration. GFP fluorescence was detected predominantly in the chloroplasts of uninfected protoplasts isolated from mock-inoculated leaves of $N$. benthamiana and faintly in the cytosol of some uninfected protoplasts (Fig. 5B, top panel). In protoplasts isolated from virusinfected tissue, GFP fluorescence was also detected in chloroplasts; however, in contrast with uninfected protoplasts, fluorescence was bright in the cytosol (Fig. 5B, bottom panel). This indicated that PsbP-GFP accumulated in the cytosol during virus infection, suggesting that $\mathrm{CP}$ sequestered endogenous PsbP in the cytosol.

\section{PsbP overexpression negatively modulates AMV replication.}

The interaction of virus proteins with host proteins can positively or negatively affect virus replication. Therefore, to determine whether the CP-PsbP interaction affects AMV replication, cellular PsbP levels were augmented by expression of exogenous YFP-PsbP in $N$. benthamiana by agroinfiltration, which was monitored by fluorescence microscopy (Fig. 6A). At 2 days after infiltration, the leaves were mechanically inoculated with either AMV RNA or virions and the inoculated leaf tissues were collected 3 days later. Tissue samples from all inoculated plants expressing YFP-PsbP accumulated approximately $60 \%$ as much virus as did those that were not expressing YFP-PsbP (Fig. 6B). Infections initiated by both RNA and virions were negatively affected by excess PsbP, which indicates that the presence of $\mathrm{CP}$ in the infecting virions had no ameliorative effect. Our results strongly suggest that PsbP is a negative regulator of AMV replication and that it may interfere with one or more of the many roles of CP in AMV replication.

\section{DISCUSSION}

Disruption of cellular protein synthesis by cyclohexamide or actinomycin D treatments inhibits AMV replication in inoculated protoplasts (Alblas and Bol 1977), and inhibition of host mRNA and protein synthesis in protoplasts by UV light pretreatment greatly reduces the accumulation of AMV RNA1 and RNA2 (Samac et al. 1983), suggesting that ongoing protein synthesis is required for productive AMV infection. Our study identified a number of host proteins, which are likely to be important in AMV infection, by an SRS.Y2H screen that detects protein interactions in the yeast cytoplasm, a cellular milieu similar to the plant cytoplasm where AMV replicates. The screen identified AtcDNAs that were all in frame with the Myr signal sequence to produce authentic fusion proteins, which are listed in Table 1. The AMV CP-Hsc70-3 interaction might likely be important for AMV replication, as has been shown for many viruses (Mayer 2005). Hsc70-3 is a cytoplasmic constitutively expressed protein, belonging to the highly conserved family of 70-kDa heat-shock proteins which, as molecular chaperones, are required for proper protein folding (Sung et al. 2001). This protein was found to be an integral component of the Turnip mosaic virus replicase complex (Dufresne et al. 2008) and Hsp70 homologs play multiple roles in Tomato bushy stunt virus replication in yeast and plants (Pogany et al. 2008; Wang et al. 2009a and b). Hsp70 and a co-chaperone, which were found in virus replication complexes, were shown to be required for replication-associated translation of Potato virus $A$ in $N$. benthamiana (Hafren et al. 2010). The CPHsc70-3 interaction is also of interest in the context of AMV CP's well-established role in cell-to-cell movement (van der Vossen et al. 1994). Three plant-encoded Hsc70 proteins of
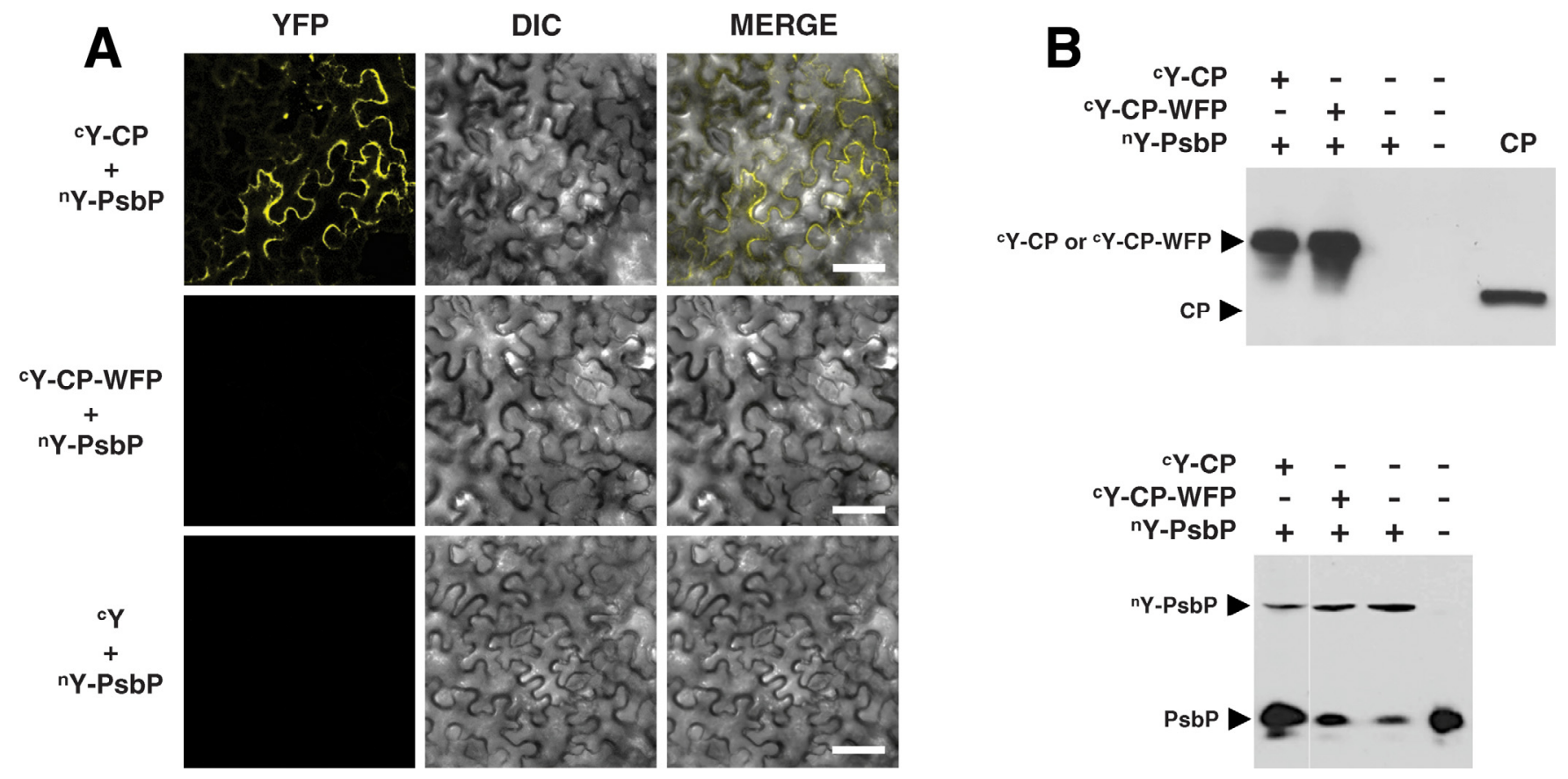

Fig. 4. Coat protein (CP)-PsbP interactions in vivo by bimolecular fluorescence complementation (BiFC). A, CP-PsbP interaction in vivo. Fusion proteins ${ }^{\mathrm{c}} \mathrm{Y}-\mathrm{CP}$ or ${ }^{\mathrm{c}} \mathrm{Y}-\mathrm{CP}-\mathrm{WFP}$, or ${ }^{\mathrm{c}} \mathrm{Y}$ portion of yellow fluorescent protein (YFP) were expressed along with ${ }^{\mathrm{n}} \mathrm{Y}$-PsbP by agroinfiltrating the encoding plasmids into leaves of Nicotiana benthamiana. The BiFC-induced YFP fluorescence in discs from infiltrated leaves was monitored at 2 days postinfiltration by confocal microscopy. Fusion protein combinations expressed in each sample are indicated at the left of the corresponding row of images. Scale bars represent $50 \mu \mathrm{m}$. B, Accumulation of the fusion proteins in N. benthamiana. Agroinfiltrated plant tissue was assayed by immunoblot analysis with anti-CP antibody (top) or anti-PsbP antibody (bottom). Plasmids agroinfiltrated into each sample are indicated above the blots. The right lane on the top blot contains CP from purified virions. Identities of the protein bands are indicated at the left. 
Cucurbita maxima traffic through plasmodesmata (PD) (Aoki et al. 2002), and Beet yellows Closterovirus encodes an Hsp70 homolog required for the cell-to-cell movement of the virus (Prokhnevsky et al. 2002). Similarly, the interaction between AMV CP and ADF3 identified in this study may also have implications in AMV cell-to-cell movement. ADF3 is one of 12 members of an actin-binding family of proteins in Arabidopsis, which mediate actin depolymerization to remodel the cytoskeleton (Maciver and Hussey 2002). A number of plant virus MPs associate with actin to facilitate the movement of virus or virus nucleoprotein complexes to the adjacent cell. Both Tobacco mosaic virus (TMV) and Cucumber mosaic virus (CMV) MPs sever actin filaments and, thereby, increase the size exclusion limit (SEL) of the PD ( $\mathrm{Su}$ et al. 2010), as do actin depolymerizing agents alone in healthy cells (Ding et al. 1996). As an essential cofactor for AMV cell-to-cell movement, the AMV CP may interact with and modulate the function of ADF3 to increase the SEL of PD in infected cells. The interaction between $\mathrm{AMV} \mathrm{CP}$ and $\alpha \mathrm{NAC}$ represents another potential virus-host interplay in AMV cell-to-cell movement. Members of the NAC family of proteins interact with newly synthesized polypeptides emerging from ribosomes and prevent unproductive interactions with other cytoplasmic factors (Rospert et al. 2002; Wegrzyn et al. 2006). An $\alpha$ NAC ortholog from $N$. benthamiana has been shown to bind to the MP of Brome mosaic virus and delay its localization to the PD, thereby reducing cell-to-cell movement and virus spread (Kaido et al. 2007). Hence, the $\mathrm{CP}-\alpha \mathrm{NAC}$ association has potential consequences for AMV spread. The glycine-rich protein 9 (GRP9) identified in the positive $\mathrm{Y} 2 \mathrm{H}$ clone CP-SRS-30 is a member of a large and divergent protein family, whose members all contain repetitive glycine-rich motifs but have diverse functions. GRP9 interacts with a protein in the lignin biosynthesis pathway (Mangeon et al. 2010), suggesting that it is involved in cell wall structure. Perhaps its role during AMV infection is analogous to another GRP, cdiGRP, which, when upregulated, restricts the systemic movement of Turnip veinclearing virus by the deposition of callose (Ueki and Citovsky 2002). The chloroplast protein ACRII and the $\alpha / \beta$-hydrolases superfamily protein identified in our $\mathrm{Y} 2 \mathrm{H}$ screen have not yet been implicated in virus pathogenesis. Intriguingly, no translation initiation factors were found to interact with $\mathrm{CP}$ in the
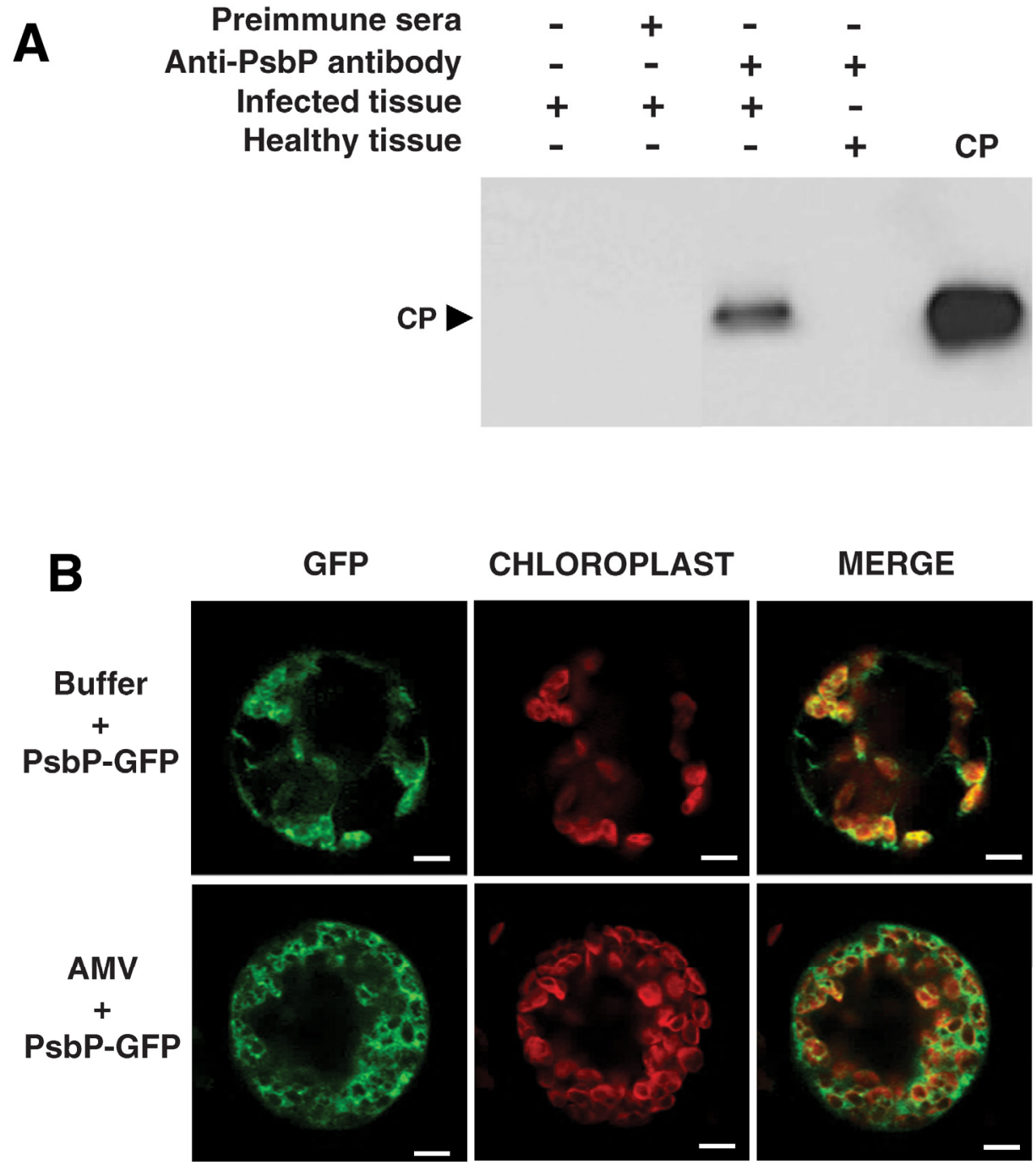

CHLOROPLAST

MERGE
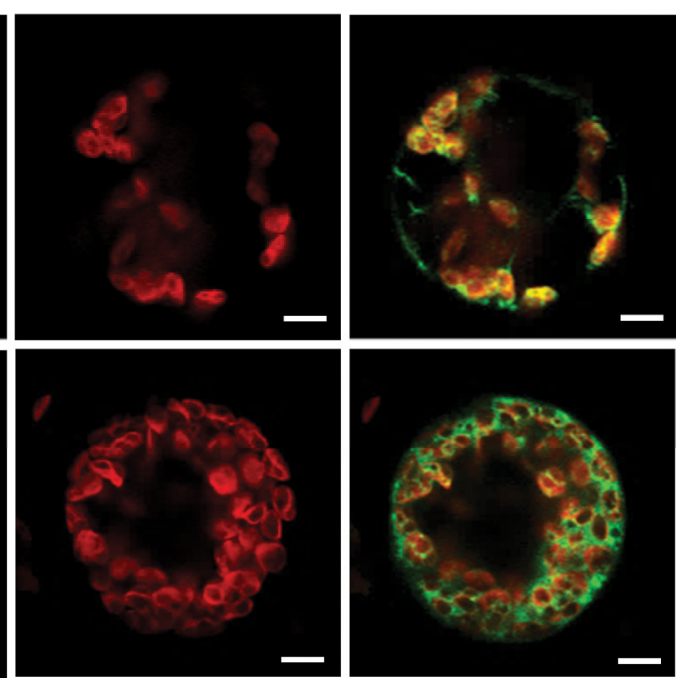

Fig. 5. Coat protein (CP)-PsbP complex formation in vivo. A, Interaction of CP with endogenous PsbP in planta during AMV infection. Total protein lysates from AMV-infected and healthy Nicotiana benthamiana leaves were subjected to pull-down assays with anti-PsbP antibodies, and the immunoprecipitated complexes were assayed by immunoblot analysis with anti-CP antibody. Components added to the samples in each lane are indicated above the blot. The right lane contains $\mathrm{CP}$ from purified virions. The position of $\mathrm{CP}$ is indicated at the left. B, Localization of PsbP-green fluorescent protein (GFP) in virusinfected protoplasts. Half-leaves of $N$. benthamiana were inoculated with AMV at $50 \mu \mathrm{g} / \mathrm{ml}$ or mock inoculated with buffer and, 2 days later, the plasmid encoding PsbP-GFP was introduced by agroinfiltration. Four days after inoculation, protoplasts were isolated from the tissues and imaged by confocal microscopy. Leaf treatments are indicated at the left. Scale bars represent $10 \mu \mathrm{m}$. 
SRS.Y2H assays, such as eIF4G, which has been reported to bind AMV CP in vitro by GST pull-down and far-Western assays (Krab et al. 2005).

The CP-interacting PsbP protein identified in our SRS.Y2H screen and subsequently confirmed in the yeast retransformation assays is a component of the multiprotein OEC, which is a constituent of PSII. It is a nuclear-encoded protein that harbors an amino-terminal bipartite transit peptide sequence to enable the proprotein to target and localize at the chloroplast thylakoid membrane. The PsbP-encoding pMyr-cDNA plasmid isolated from the positive yeast colony harbored the PsbP proprotein open reading frame (ORF), which includes the transit peptide.

AMV CP interacted with PsbP in vitro, in planta, and in AMV-infected plant tissue. In the in vitro pull-down, ${ }^{35} \mathrm{~S}$-PsbP synthesized in a cell-free translation system preferentially associated with GST-CP compared with the GST control. The $\mathrm{BiFC}$ assays demonstrated that AMV CP interacted with PsbP in $N$. benthamiana, while CP mutants with amino acid substitutions that disrupt dimerization (Choi and Loesch-Fries 1999) failed to interact with PsbP, thereby suggesting that CP dimerization is essential for interaction with PsbP. The structure of AMV CP has been solved to $4.0 \AA$ for $\mathrm{CP}$ in $\mathrm{T}=1$ particles made up of dimers (Kumar et al. 1997). Perhaps a PsbP binding site is formed upon dimerization of $\mathrm{CP}$, in which amino acids from the $\mathrm{C}$ terminus of one $\mathrm{CP}$ subunit hook around the $\mathrm{N}$ terminus of the other subunit.

Immunoprecipitation of AMV-infected tobacco lysates with anti-PsbP antibodies pulled down PsbP-CP complexes demonstrating a specific interaction between the endogenous $N$. benthamiana PsbP and CP during AMV infection. There are four isoforms of PsbP expressed in $N$. benthamiana, which are approximately $83 \%$ similar in amino acid sequence to that of Arabidopsis (Perez-Bueno et al. 2011). This suggests that this virus-host protein interaction is conserved between hosts and has potentially functional roles in AMV infection. This was further strengthened by the finding that a significant amount of PsbP was sequestered in the cytosol during virus infection. If PsbP is a cellular cofactor required for AMV replication, such as a component of the replication complex, overexpression of it in host plants would likely increase virus replication. However, virus accumulation was significantly reduced upon PsbP overexpression in $N$. benthamiana. This finding suggests that endogenous PsbP negatively regulates AMV infection.

Viruses and chloroplast proteins have a long and complex history together. Virus infection of plants induces the development of various patterns of chlorosis, which indicate damage to chloroplasts. Several viruses, including Plum pox virus, Potato virus $Y$, Soybean mosaic virus, Sugarcane mosaic virus, Shallot yellow stripe virus, Potato virus $X$, TMV, Papaya ringspot virus, Hibiscus chlorotic ringspot virus, and Alternanthera mosaic virus have all been shown to encode proteins that interact with a chloroplast protein or with a component of the photosynthetic machinery (Abbink et al. 2002; Bhat et al. 2013; Cheng et al. 2008; Gao et al. 2012a and b; Jang et al. 2013; Jimenez et al. 2006; Jin et al. 2007; Prod'homme et al. 2003; Qiao et al. 2009; Seo et al. 2007). Two virus-centric models likely explain such virus-host protein interactions: a maneuvering by the virus to facilitate its replication on or in the chloroplast, or a virus-orchestrated sequestration strategy whereby the interacting host protein is blocked from activating host defense responses. We and others have shown that AMV replication is associated with the tonoplast (Ibrahim et al. 2012; van der Heijden et al. 2001), and results presented here show that overexpression of PsbP inhibits AMV replication; hence, the latter scenario is most plausible. However, we cannot rule out a plant-centric model. The $\mathrm{CP}$ may play a rela- tively passive role while PsbP adopts a proactive role in plant defense, potentially assisted by other cellular machinery. For example, during TMV infection of $\mathrm{N}$-gene-containing tobacco plants, a tobacco chloroplast protein, NRIP1, interacts with the TMV replicase protein. This protein complex subsequently interacts with and activates the $\mathrm{N}$ protein to result in the hypersensitive response (Caplan et al. 2008). Because our data demonstrate that PsbP binds only to CP dimers, PsbP could conceivably bind to the capsid lattices of incoming virions to form complexes recognized by a host protein that activates defense pathways.

The chloroplast generates a number of host defense responserelated signaling molecules, as well as being the location of defense related proteins such as NRIP1. An oxidative burst releasing reactive oxygen species (ROS) is one of the earliest responses upon pathogen invasion. It is produced in several locations in the cell, including photosystem I and PSII in the thylakoid membrane of the chloroplast (Sharma et al. 2012). The signaling hormone salicylic acid (SA) is made in and exported from the chloroplast and is involved in systemic acquired resistance against infection by a variety of pathogens, including viruses (Spoel and Dong 2012). It is possible that AMV CP is an effector protein, as defined by Mandadi and Scholthof (2013), that interacts with PsbP to interfere with host defense signaling. AMV CP may sequester the chloroplast-targeted PsbP in the cytosol, thereby preempting the biogenesis of PSII and the consequent augmented generation of
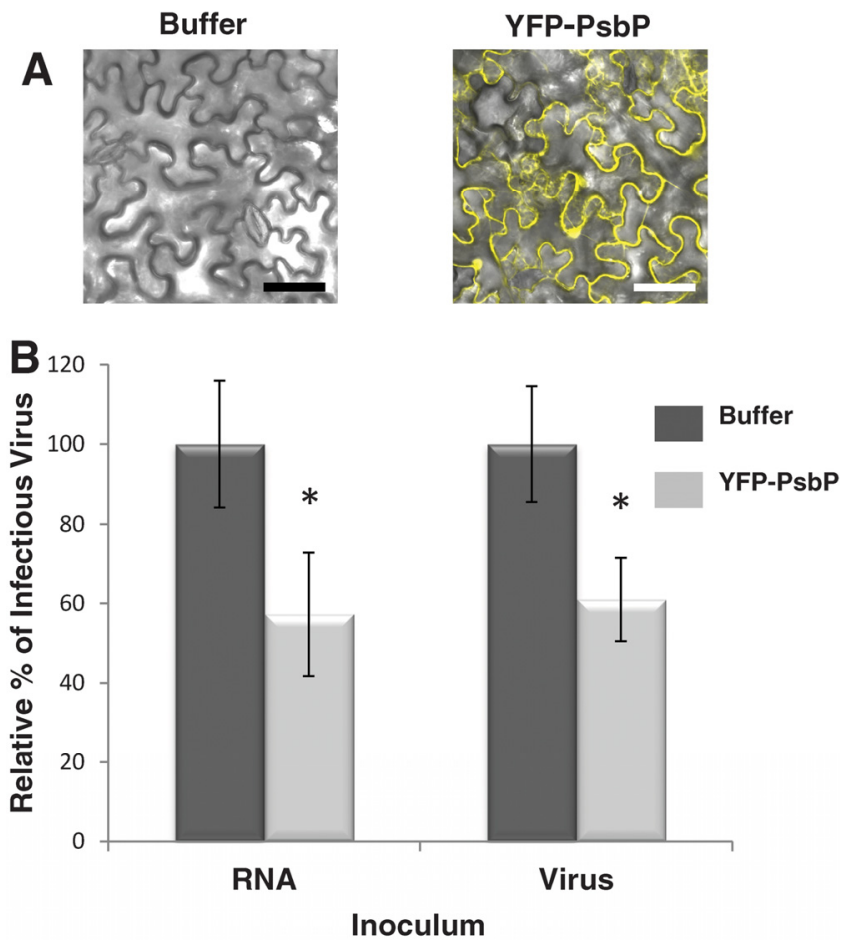

Fig. 6. Effect of PsbP overexpression on virus replication. A, Expression of yellow fluorescent protein (YFP)-PsbP in agroinfiltrated leaves of Nicotiana benthamiana. Either buffer alone or the plasmid encoding YFP-PsbP was infiltrated into leaves of $N$. benthamiana and YFP fluorescence was monitored at 2 days postinfiltration with a confocal microscope. Scale bars represent $50 \mu \mathrm{m}$. B, Determination of virus replication levels. Two days after infiltration, the infiltrated leaves of control plants and YFP-PsbPexpressing plants were inoculated with viral RNA or virus. Three days later, tissue homogenates from the inoculated leaves were analyzed by local lesion assay on leaves of Vigna sinensis. The relative amount of virus was determined by comparing the average number of local lesions produced by samples from plants expressing YFP-PsbP to the average number produced by samples from buffer-infiltrated plants. Asterisks indicate statistical significance (Tukey with $P<0.05$ ). 
ROS and activation of plant defense responses. Such a strategy has been suggested for the interaction of chloroplast proteins with the TMV replicase protein and the Plum pox virus CI protein (Abbink et al. 2002; Jimenez et al. 2006) and, recently, for the interaction of Rice stripe virus SP protein with rice PsbP (Kong et al. 2014). Such pathogen-effector-induced modulation of chloroplast integrity and function is not a virus-exclusive strategy for evading host defense responses. The cysteine protease HopN1, a Pseudomonas syringae-encoded effector protein, was shown to localize to the thylakoids of chloroplasts wherein it bound the PSII OEC protein PsbQ and promoted its degradation (Rodriguez-Herva et al. 2012). The resultant interruption of PSII activity and suppression of ROS production compromised programmed cell death. This specifically implicates PSII and an OEC protein in plant innate immune responses.

PsbQ appears to be involved in stabilizing the binding of PsbP in PSII (Kakiuchi et al. 2012), where PsbP is essential for PSII function (Ifuku et al. 2005). Both proteins are important in maintaining an optimal calcium and chloride concentration in the OEC, which is vital for the reaction center where water is oxidized (Bricker et al. 2012; Vinyard et al. 2013). Nevertheless, OEC proteins are among those downregulated by viruses (Lehto et al. 2003). For example, proteomic analyses have shown specific downregulation of PsbP protein by Pepper mild mottle virus (Perez-Bueno et al. 2004) and CMV (Di Carli et al. 2010). Furthermore, microarray analyses have shown that, in addition to genes for OEC proteins, many other chloroplast genes are downregulated by a number of diverse plant viruses (Babu et al. 2008; Gongora-Castillo et al. 2012; Gonzalez-Ibeas et al. 2012; Herranz et al. 2013).

Further evidence supporting a major role for chloroplasts in the positive regulation of plant immunity was recently provided by the revelation of a novel signaling nexus between chloroplasts and the cytoplasmic-nuclear immune system. Plant immunity is generally considered to trigger two complementary signal transduction pathways: the chloroplast-orchestrated pathway that generates ROS and SA and the cytoplasmic mitogen-activated protein kinase and $\mathrm{Ca}^{2+}$ signaling pathways leading to transcriptional reprograming in the nucleus. A recent study revealed a novel pathway linking chloroplasts to cytoplasmic and nuclear immune responses (Nomura et al. 2012). Two pathogen-associated molecular pattern signals, bacterial flagellin peptide (Flg22) and fungal chitin, induced a long-lasting $\mathrm{Ca}^{2+}$ increase in the chloroplast stroma. A thylakoid membrane-bound protein, calcium-sensing receptor protein (CAS), was shown to mediate this $\mathrm{Ca}^{2+}$ increase, potentially by releasing $\mathrm{Ca}^{2+}$ sequestered in the thylakoid. CAS regulates SA synthesis, which occurs in the chloroplast (Fragniere et al. 2011; Strawn et al. 2007), by activation of transcriptional factors necessary for SA biosynthesis enzymes and for EDS5, which is required for the transport of SA to the cytoplasm (Serrano et al. 2013). Relevantly, the OEC proteins PsbP and PsbO bind and release $\mathrm{Ca}^{2+}$ during biogenesis and turnover of PSII (Spetea 2012). These proteins, therefore, could function as sources of $\mathrm{Ca}^{2+}$ signaling in the chloroplast, which is monitored by CAS. Hence, taken together, AMV CP interaction with PsbP may set the stage for impaired biogenesis of PSII, reduced $\mathrm{Ca}^{2+}$ signaling, and subsequent reduction in ROS and SA synthesis so that AMV could more efficiently replicate in host cells.

\section{MATERIALS AND METHODS}

\section{Plasmid vectors.}

To construct the pSos-CP bait plasmid for use in the SRS.Y2H assays (CytoTrapXR; Stratagene, La Jolla, CA,
U.S.A.), the CP ORF from pSP65A4 (Loesch-Fries et al. 1985) was amplified by polymerase chain reaction (PCR) with primer set 1 (Supplementary Table S1), which includes a forward primer with an NcoI site and a reverse primer with a SalI site. The PCR product was digested with NcoI and SalI enzymes, then cloned into NcoI/Sall-digested pSos plasmid (Stratagene) to yield pSos-CP. To construct the pGEX-CP bacterial expression plasmid encoding a GST-CP fusion protein, the CP ORF from pSP65A4 plasmid was amplified by PCR with forward and reverse primers (primer set 7) harboring EcoRI and SalI sites, respectively. The resulting CP ORF amplicon was subcloned into the pGEM-T plasmid (Promega Corp., Madison, WI, U.S.A.) by using the TA cloning procedure. The resulting plasmid, pGEM-T-CP, was digested by EcoRI and SalI enzymes and the released CP ORF insert was ligated to compatible sites of pGEX-4T-3 (GE Healthcare, Piscataway, NJ, U.S.A.) to yield pGEX-CP. To construct a PsbPencoding plasmid suitable for in vitro transcription or translation, the PsbP ORF in clone CP-SRS-12 (Table 1) was amplified by PCR with primer set 8 and ligated downstream of the T7 promoter in the pGEM-T plasmid. The resultant plasmid was digested with $N c o$ I enzyme and religated to remove the redundant translational start codon located upstream of the PsbP ORF in the vector backbone to yield pGEM-T-PsbP.

The Gateway-mediated recombination cloning strategy was used to generate the BiFC plasmids. The Gateway attB1 or attB2 sequences were added to the $5^{\prime}$ or $3^{\prime}$ end, respectively, of the ORF of CP, CP mutants, and PsbP. The ORF of CP, CP-W, and CP-WFP (Choi and Loesch-Fries 1999) were amplified from pSP65A4 by PCR with primer set 2,4 , or 5 , respectively with Phusion High Fidelity DNA polymerase (Finnzymes; Thermo Scientific, Rockville, IL, U.S.A.). The PsbP ORF was amplified from SRS-Y2H clone CP-SRS-12 (Table 1) by PCR with primer set 3 to place a YFP tag at the $\mathrm{N}$ terminus of PsbP, or primer set 3 without the stop codon to place a GFP tag at the $\mathrm{C}$ terminus. The PCR amplicons were recombined into the pDONR221 vector (Invitrogen, Grand Island, NY, U.S.A.) as per the manufacturer's recommendations to yield Gateway entry clones. After sequence validation, entry clone DNA of each plasmid was mobilized into Agrobacterium binary pSITE vectors (Chakrabarty et al. 2007) in a Gateway LR clonase-catalyzed reaction as per the manufacturer's guidelines. All pSITE clones were confirmed by restriction enzyme digestion and agarose gel analysis.

\section{Analysis of protein interactions by SRS-based Y2H assays.}

The SRS.Y2H system (Stratagene) was used to screen and identify CP-interacting Arabidopsis proteins. The Arabidopsis CytoTrap XR library (SRS.Y2H library) was prepared, as per the manufacturer's recommendations (Stratagene), from mature A. thaliana plants (Wassilewskija ecotype) harvested $4 \mathrm{~h}$ after spraying with $2 \mathrm{mM}$ SA (Chen et al. 2004). Transformation of yeast cells with the plasmid constructs and evaluation of protein interactions were performed as described in the manufacturer-supplied protocol. To confirm that AMV CP could be used as a bait, competent cdc $25 \mathrm{H}$ cells were transformed with pSos-CP and selected at 25 or $37^{\circ} \mathrm{C}$ on $\mathrm{SD} /$ galactose (-L) or SD/glucose (-L) (Sigma-Aldrich, St. Louis). To identify Arabidopsis proteins that interacted with $\mathrm{CP}$, cdc25H cells were co-transformed with pSos-CP and the plasmids in the SRS.Y2H library and subsequently selected at the permissive temperature of $25^{\circ} \mathrm{C}$ on $\mathrm{SD} /$ glucose (-UL). Transformants harboring pSos and plasmids from the SRS.Y2H served as negative controls. After 2 days of growth on SD/glucose (-UL) medium at $25^{\circ} \mathrm{C}$, colonies were replicaplated onto $\mathrm{SD} /$ galactose (-UL) medium and grown at $37^{\circ} \mathrm{C}$ to identify positive colonies. Colonies that grew at $37^{\circ} \mathrm{C}$ were 
subsequently patched onto SD/glucose (-UL) medium and maintained at $25^{\circ} \mathrm{C}$ to repress the GAL1-promoter-induced expression of candidate interacting proteins. The repressed colonies were then patched onto two plates containing SD/glucose (-UL) medium and one plate containing SD/galactose (-UL) medium. The SD/galactose (-UL) plate and one of the $\mathrm{SD} /$ glucose (-UL) plates were maintained at $37^{\circ} \mathrm{C}$, while the other SD/glucose $(-\mathrm{UL})$ plate was incubated at $25^{\circ} \mathrm{C}$ to serve as a repatching source. Colonies that grew only on $\mathrm{SD} /$ galactose (-UL) but not on SD/glucose (-UL) at $37^{\circ} \mathrm{C}$ were subjected to a second selection by repeating the same procedure. Colonies selected after two rounds of galactose-dependent growth at $37^{\circ} \mathrm{C}$ were considered "putative positives". These were further verified by co-transforming yeast cells with appropriate bait plasmids and SRS.Y2H library cDNAs isolated from the putative positives and testing for galactose-dependent growth at $37^{\circ} \mathrm{C}$. A yeast transformant that harbored pSos and the appropriate isolated library cDNA served as the negative control. All preparations of cdc $25 \mathrm{H}$ competent cells were tested for temperature-sensitive revertants as recommended by the manufacturer. The pMyr-AtcDNA plasmids from the SRS.Y2H library clones were isolated as per the manufacturer's recommendations (Stratagene) and were mobilized into Escherichia coli DH5 $\alpha$ (Invitrogen). Plasmid DNA was extracted from overnight-grown bacterial cultures and DNA sequence analyses were performed with primer set 6 , which binds to $5^{\prime}$ - and $3^{\prime}$-end flanking vector sequences. The resulting DNA sequences were compared with sequences deposited in the NCBI public database. Further information about the interacting Arabidopsis proteins was obtained from The Arabidopsis Information Resource Center website.

\section{Production of recombinant proteins in vitro and in $E$. coli.}

For in vitro transcription, the plasmid DNA templates pSP65A4 and pGEM-T-PsbP were linearized by digestion with $S m a I$ and SalI enzymes, respectively. The linearized plasmids were transcribed in vitro with SP6 or T7 RNA polymerase, respectively, supplied with the Riboprobe systems (Promega Corp.). ${ }^{35}$ S-labeled recombinant proteins were synthesized in vitro from plasmid DNAs with the TNT T7 Coupled Reticulocyte System (Promega Corp.) or from in vitro transcribed RNA with wheat germ extract (Promega Corp.) or from virion-purified RNA with rabbit reticulocyte lysate (Promega Corp.), as per the manufacturer's recommendations. To express GST or GST-CP, starter cultures from single colony picks of Rosetta 2 (DE3) bacteria (Novagen; EMD Millipore, Billerica, MA, U.S.A.) harboring the pGEX or pGEX-CP plasmids, respectively, were grown overnight at $37^{\circ} \mathrm{C}$. Aliquots $(500 \mu \mathrm{l})$ of starter cultures were inoculated into $50 \mathrm{ml}$ of Luria Bertani broth (10 $\mathrm{g}$ of tryptone, $5 \mathrm{~g}$ of yeast extract, and $10 \mathrm{~g}$ of $\mathrm{NaCl}$ in 1 liter) supplemented with appropriate antibiotics, and the bacteria were cultured at $37^{\circ} \mathrm{C}$, with shaking at $250 \mathrm{rpm}$ until an optical density at $600 \mathrm{~nm}\left(\mathrm{OD}_{600}\right)$ of 0.7 was reached. The bacterial cultures were then supplemented with $0.1 \mathrm{mM}$ isopropylthio- $\beta$-glactoside and incubated for another $6 \mathrm{~h}$ at room temperature, with shaking at $250 \mathrm{rpm}$. The cells were harvested by centrifugation $(5,300 \times g)$, and the pellets were washed with ice-cold $20 \mathrm{mM}$ Tris- $\mathrm{HCl}$ (pH 8.0), resuspended in $10 \mathrm{ml}$ of the wash buffer, and divided into 1-ml aliquots of cells, which were collected by centrifugation and stored at $-80^{\circ} \mathrm{C}$ until use. To analyze the expression levels and the solubility of the recombinant proteins, individual pellets were resuspended in phosphate-buffered saline (PBS) $(137 \mathrm{mM} \mathrm{NaCl}, 2.68 \mathrm{mM}$ $\mathrm{KCl}, 1.47 \mathrm{mM} \mathrm{KH}{ }_{2} \mathrm{PO}_{4}$, and $8.1 \mathrm{mM} \mathrm{Na}_{2} \mathrm{HPO}_{4}, \mathrm{pH}$ 7.4) supplemented with protease inhibitors (cOmplete Mini EDTA-free Protease Inhibitor Cocktail; Roche Applied Science, Indianapolis, IN, U.S.A.). The cells were subjected while on ice to five to seven 10-s bursts with a microtip sonicator (Sonifier 450; Branson Ultrasonics, Sonitek, Milford, CT, U.S.A.) set on a duty cycle of 50 to $60 \%$ and an output of 5 to 6 . The homogenate was centrifuged at $15,000 \times g$ for $30 \mathrm{~min}$ and the pellet (insoluble) and the supernatant (soluble) fractions were collected and stored at $-80^{\circ} \mathrm{C}$ until use. Aliquots of the pellet and supernatant fractions were mixed with equal volumes of a $2 \times$ concentration of sodium dodecyl sulfate (SDS) loading buffer (50 mM Tris- $\mathrm{HCl}$ [pH 6.8], 2\% [wt/vol] SDS, 0.1\% [wt/vol] bromophenol blue, $10 \%$ [vol/vol] glycerol, and $100 \mathrm{mM} \beta$ mercaptoethanol), boiled for 5 to $10 \mathrm{~min}$ and, centrifuged at $2,000 \times g$ for $10 \mathrm{~min}$. Aliquots of the supernatants were analyzed by SDS polyacrylamide gel electrophoresis (PAGE).

\section{Pull-down and co-immunoprecipitation assay.}

The pull-down assays with GST fusion proteins were performed with the MagneGST protein purification system (Promega Corp.) as per the manufacturer's instructions. Briefly, pGEX-encoded GST protein or pGEX-CP-encoded GST-CP fusion protein from the soluble fraction of bacterial lysate was immobilized onto MagneGST Glutathione Particles (Promega Corp.) by incubation at $4^{\circ} \mathrm{C}$ for 60 to 90 min on a rotary shaker. The protein-bound particles were collected with a magnet and washed with MagneGST binding or wash buffer (4.2 $\mathrm{mM} \mathrm{N}_{2} \mathrm{HPO}_{4}, 2 \mathrm{mM} \mathrm{K} \mathrm{HPO}_{4}, 140 \mathrm{mM} \mathrm{NaCl}$, and $10 \mathrm{mM}$ $\mathrm{KCl})$ and suspended in the binding and wash buffer. The particles were incubated at room temperature with ${ }^{35} \mathrm{~S}$-labeled prey proteins, which had been translated in vitro, for 1 to $2 \mathrm{~h}$ with gentle shaking. The particles were washed again with binding and wash buffer, collected with a magnet, incubated with SDS loading buffer, and boiled for $10 \mathrm{~min}$. The particles were magnetically captured and eluates were analyzed by SDS-PAGE in $10 \%$ gels.

For co-immunoprecipitation assays, antibodies were bound to magnetic Protein A Dynabeads (Invitrogen) by incubating them with anti-PsbP rabbit polyclonal antibodies (Abcam, Cambridge, MA, U.S.A.) for $10 \mathrm{~min}$ at room temperature with gentle shaking. The primary antibodies were crosslinked to the Dynabeads with bis(sulfosuccinimidyl) suberate (Thermo Scientific) as per the vendor's instructions and described by the supplier. Plant tissue $(200 \mathrm{mg}$ ) was homogenized in $100 \mu \mathrm{l}$ of PBS buffer, vortexed for $1 \mathrm{~min}$, then centrifuged at $4^{\circ} \mathrm{C}$ for 15 $\min$ at $16,000 \times g$. Aliquots of the supernatant $(100 \mu \mathrm{l})$ were incubated with the anti-PsbP Dynabeads for $15 \mathrm{~min}$ at room temperature. The beads were captured with a magnet and washed three times with $200 \mu \mathrm{l}$ of PBS. Bound proteins were eluted with $50 \mathrm{mM}$ glycine, $\mathrm{pH} 2.8$; an equal volume of a $2 \times$ concentration of SDS loading buffer was added; and the sample was boiled for $10 \mathrm{~min}$. Proteins were resolved by SDSPAGE in a $12 \%$ gel and transferred to polyvinylidene difluoride membranes. Membranes were probed with the anti-PsbP antibody (1:5000 dilution) or with the anti-CP antibody (1:7000 dilution). Primary antibodies were detected with horseradish peroxidase-conjugated anti-rabbit immunoglobulin G (Rockland Immunochemicals, Gilbertsville, PA, U.S.A.) at a $1: 10,000$ dilution and their position on the membrane was visualized with a chemiluminescent substrate (Pierce ECL; Thermo Scientific).

\section{Agrobacterium-mediated transient expression.}

$N$. benthamiana seeds were germinated in soil (Metromix; Sungro, Agawam, MA, U.S.A.) and transplanted 2 weeks later. Plants were fertilized weekly with Miracle-Gro (The Scotts Company LLC, Marysville, OH, U.S.A.) at half the recommended strength and were maintained with $16 \mathrm{~h}$ of daily illumination. For agroinfiltration experiments, 5- to 8-week-old plants were used. Recombinant pSITE plasmid constructs were 
electroporated into Agrobacterium tumefaciens LBA4404 at $2,400 \mathrm{~V}, 25 \mu \mathrm{F}$, and $200 \mathrm{ohms}$ in a 1-mm cuvette (Genepulser Xcell; Bio-Rad, Hercules, CA, U.S.A.). Transformed cells were streaked onto media containing $50 \mathrm{mM}$ spectinomycin and $20 \mathrm{mM}$ rifampicin and incubated at $28^{\circ} \mathrm{C}$ for 2 days. Transformation of bacterial colonies was confirmed by PCR, and single colonies of bacterial cells were grown in $3 \mathrm{ml}$ of YEP (10 g of yeast extract, $10 \mathrm{~g}$ of peptone, and $5 \mathrm{~g}$ of $\mathrm{NaCl}$ in 1 liter) to an $\mathrm{OD}_{600}$ of 0.6 to 1.0 for agroinfiltration, as previously described (Chakrabarty et al. 2007). Briefly, $2 \mathrm{ml}$ each of the bacterial cultures was harvested by centrifugation, the bacterial pellets were suspended in agroinfiltration buffer (10 $\mathrm{mM} \mathrm{MgCl} 2$ and $50 \mathrm{mM}$ morpholinoethanesulfonic acid, $\mathrm{pH}$ 5.4) to which $200 \mu \mathrm{M}$ acetosyringone (Sigma-Aldrich) was added, and the contents were incubated for $3 \mathrm{~h}$ at room temperature. The induced agrobacterium cells were infiltrated into the abaxial surface of $N$. benthamiana leaves with a $1-\mathrm{ml}$ syringe.

To determine the effect of PsbP overexpression on virus replication, leaves of $N$. benthamiana were mechanically inoculated with either AMV RNA at $100 \mu \mathrm{g} / \mu \mathrm{l}$ or virus at $3 \mu \mathrm{g} / \mu \mathrm{l}$ $48 \mathrm{~h}$ after infiltration of buffer or agrobacteria containing pYFP-PsbP. The tissue was harvested 3 days postinoculation and the relative amount of virus replication was determined by local lesion assay. Briefly, leaf tissue was homogenized with $0.03 \mathrm{M}$ phosphate buffer, $\mathrm{pH} 8.0$, and mechanically inoculated to leaves of Vigna sinensis in a Latin square design. Lesions were counted 3 days postinoculation and analyzed with the analysis of variance 9.0 with SPSS.

\section{Protoplast isolation.}

Protoplasts were isolated from leaves of $N$. benthamiana as previously described (Ibrahim et al. 2012). Briefly, cells were digested in an enzyme mixture containing $2 \%$ cellulysin (Calbiochem, San Diego, CA, U.S.A.), 0.1\% pectolyaseY-23 (MP Biomedical, Solon, OH, U.S.A.), and $400 \mathrm{mM}$ mannitol for 90 min at $30^{\circ} \mathrm{C}$ with gentle shaking. The protoplasts were collected by centrifugation at $50 \times g$ for 2 min and suspended in $400 \mathrm{mM}$ mannitol for examination by confocal microscopy.

\section{Plant sample preparation and imaging.}

Sections of $N$. benthamiana leaves were mounted in water $48 \mathrm{~h}$ after agroinfiltration and imaged with a Zeiss 710 laserscanning confocal microscope. Native YFP and reconstituted YFP were detected by excitation at $514 \mathrm{~nm}$ with a 519- to 621$\mathrm{nm}$ band pass emission filter; GFP was detected by excitation at $488 \mathrm{~nm}$ with a 493 - to 598-nm band pass emission filter. Chloroplasts were identified by excitation at $633 \mathrm{~nm}$ with a 647- to 721-nm pass emission filter.

\section{ACKNOWLEDGMENTS}

We thank M. Goodin for advice on the bimolecular fluorescence complementation assays. The BiFC vectors were obtained from the Arabidopsis Biological Resource Center and the Arabidopsis CytoTrap XR library (SRS.Y2H library) was a kind gift from Z. Chen.

\section{LITERATURE CITED}

Abbink, T. E., Peart, J. R., Mos, T. N., Baulcombe, D. C., Bol, J. F., and Linthorst, H. J. 2002. Silencing of a gene encoding a protein component of the oxygen-evolving complex of photosystem II enhances virus replication in plants. Virology 295:307-319.

Ahlquist, P., Noueiry, A. O., Lee, W. M., Kushner, D. B., and Dye, B. T. 2003. Host factors in positive-strand RNA virus genome replication. J. Virol. 77:8181-8186.

Alblas, F., and Bol, J. F. 1977. Factors influencing infection of cowpea mesophyll protoplasts by Alfalfa mosaic virus. J. Gen. Virol. 36:175185
Ansel-McKinney, P., Scott, S. W., Swanson, M., Ge, X., and Gehrke, L. 1996. A plant viral coat protein RNA binding consensus sequence contains a crucial arginine. EMBO (Eur. Mol. Biol. Organ.) J. 15:50775084

Aoki, K., Kragler, F., Xoconostle-Cazares, B., and Lucas, W. J. 2002. A subclass of plant heat shock cognate 70 chaperones carries a motif that facilitates trafficking through plasmodesmata. Proc. Natl. Acad. Sci. U.S.A. 99:16342-16347.

Aronheim, A., Engelberg, D., Li, N., al-Alawi, N., Schlessinger, J., and Karin, M. 1994. Membrane targeting of the nucleotide exchange factor Sos is sufficient for activating the Ras signaling pathway. Cell 78:949961.

Aronheim, A., Zandi, E., Hennemann, H., Elledge, S. J., and Karin, M. 1997. Isolation of an AP-1 repressor by a novel method for detecting protein-protein interactions. Mol. Cell. Biol. 17:3094-3102.

Babu, M., Gagarinova, A. G., Brandle, J. E., and Wang, A. 2008. Association of the transcriptional response of soybean plants with soybean mosaic virus systemic infection. J. Gen. Virol. 89:1069-1080.

Baer, M. L., Houser, F., Loesch-Fries, L. S., and Gehrke, L. 1994. Specific RNA binding by amino-terminal peptides of alfalfa mosaic virus coat protein. EMBO (Eur. Mol. Biol. Organ.) J. 13:727-735.

Bailiss, K. W., and Ollennu, L. A. A. 1986. Effect of alfalfa mosaic virus isolates on forage yield of lucerne (Medicago-Sativa) in Britain. Plant Pathol. 35:162-168.

Balasubramaniam, M., Ibrahim, A., Kim, B. S., and Loesch-Fries, L. S. 2006. Arabidopsis thaliana is an asymptomatic host of Alfalfa mosaic virus. Virus Res 121:215-219.

Bhat, S., Folimonova, S. Y., Cole, A. B., Ballard, K. D., Lei, Z., Watson, B. S., Sumner, L. W., and Nelson, R. S. 2013. Influence of host chloroplast proteins on Tobacco mosaic virus accumulation and intercellular movement. Plant Physiol. 161:134-147.

Bol, J. F. 1999. Alfalfa mosaic virus and ilarviruses: Involvement of coat protein in multiple steps of the replication cycle. J. Gen. Virol. 80:10891102

Bol, J. F. 2003. Alfalfa mosaic virus: Coat protein-dependent initiation of infection. Mol. Plant Pathol. 4:1-8

Bricker, T. M., Roose, J. L., Fagerlund, R. D., Frankel, L. K., and EatonRye, J. J. 2012. The extrinsic proteins of Photosystem II. Biochim. Biophys. Acta 1817:121-142.

Bricker, T. M., Roose, J. L., Zhang, P., and Frankel, L. K. 2013. The PsbP family of proteins. Photosynth. Res. 116:235-250.

Caplan, J. L., Mamillapalli, P., Burch-Smith, T. M., Czymmek, K., and Dinesh-Kumar, S. P. 2008. Chloroplastic protein NRIP1 mediates innate immune receptor recognition of a viral effector. Cell 132:449-462.

Chakrabarty, R., Banerjee, R., Chung, S. M., Farman, M., Citovsky, V., Hogenhout, S. A., Tzfira, T., and Goodin, M. 2007. pSITE vectors for stable integration or transient expression of autofluorescent protein fusions in plants: Probing Nicotiana benthamiana-virus interactions. Mol. Plant-Microbe Interact. 20:740-750.

Chen, S. C., and Olsthoorn, R. C. 2010. In vitro and in vivo studies of the RNA conformational switch in Alfalfa mosaic virus. J. Virol. 84:14231429

Chen, Z., Kloek, A. P., Cuzick, A., Moeder, W., Tang, D., Innes, R. W., Klessig, D. F., McDowell, J. M., and Kunkel, B. N. 2004. The Pseudomonas syringae type III effector AvrRpt2 functions downstream or independently of SA to promote virulence on Arabidopsis thaliana. Plant J. 37:494-504.

Cheng, Y. Q., Liu, Z. M., Xu, J., Zhou, T., Wang, M., Chen, Y. T., Li, H. F., and Fan, Z. F. 2008. HC-Pro protein of sugar cane mosaic virus interacts specifically with maize ferredoxin-5 in vitro and in planta. J. Gen. Virol. 89:2046-2054.

Cho, S. Y., Cho, W. K., Sohn, S. H., and Kim, K. H. 2012. Interaction of the host protein NbDnaJ with Potato virus $X$ minus-strand stem-loop 1 RNA and capsid protein affects viral replication and movement. Biochem. Biophys. Res. Commun. 417:451-456.

Choi, J., and Loesch-Fries, L. S. 1999. Effect of C-terminal mutations of Alfalfa mosaic virus coat protein on dimer formation and assembly in vitro. Virology 260:182-189.

Choi, J., Kim, B. S., Zhao, X., and Loesch-Fries, S. 2003. The importance of Alfalfa mosaic virus coat protein dimers in the initiation of replication. Virology 305:44-49.

Di Carli, M., Villani, M. E., Bianco, L., Lombardi, R., Perrotta, G., Benvenuto, E., and Donini, M. 2010. Proteomic analysis of the plantvirus interaction in Cucumber mosaic virus (CMV) resistant transgenic tomato. J. Proteome Res. 9:5684-5697.

Ding, X., Shintaku, M. H., Carter, S. A., and Nelson, R. S. 1996. Invasion of minor veins of tobacco leaves inoculated with tobacco mosaic virus mutants defective in phloem-dependent movement. Proc. Natl. Acad. Sci. U.S.A. 93:11155-11160

Dufresne, P. J., Thivierge, K., Cotton, S., Beauchemin, C., Ide, C., Ubalijoro, 
E., Laliberte, J. F., and Fortin, M. G. 2008. Heat shock 70 protein interaction with Turnip mosaic virus RNA-dependent RNA polymerase within virus-induced membrane vesicles. Virology 374:217-227.

Fragniere, C., Serrano, M., Abou-Mansour, E., Metraux, J. P., and L'Haridon, F. 2011. Salicylic acid and its location in response to biotic and abiotic stress. FEBS (Fed. Eur. Biochem. Soc.) Lett. 585:18471852

Gao, L., Shen, W., Yan, P., Tuo, D., Li, X., and Zhou, P. 2012a. NIa-pro of Papaya ringspot virus interacts with papaya methionine sulfoxide reductase B1. Virology 434:78-87.

Gao, R., Ng, F. K., Liu, P., and Wong, S. M. 2012b. Hibiscus chlorotic ringspot virus coat protein upregulates sulfur metabolism genes for enhanced pathogen defense. Mol. Plant-Microbe Interact. 25:1574-1583.

Gongora-Castillo, E., Ibarra-Laclette, E., Trejo-Saavedra, D. L., and RiveraBustamante, R. F. 2012. Transcriptome analysis of symptomatic and recovered leaves of geminivirus-infected pepper (Capsicum anпиит). Virol. J. 9:295.

Gonzalez-Ibeas, D., Canizares, J., and Aranda, M. A. 2012. Microarray analysis shows that recessive resistance to Watermelon mosaic virus in melon is associated with the induction of defense response genes. Mol. Plant-Microbe Interact. 25:107-118.

Guogas, L. M., Filman, D. J., Hogle, J. M., and Gehrke, L. 2004. Cofolding organizes Alfalfa mosaic virus RNA and coat protein for replication. Science 306:2108-2111.

Hafren, A., Hofius, D., Ronnholm, G., Sonnewald, U., and Makinen, K 2010. HSP70 and its cochaperone CPIP promote potyvirus infection in Nicotiana benthamiana by regulating viral coat protein functions. Plant Cell 22:523-535.

Herranz, M. C., Niehl, A., Rosales, M., Fiore, N., Zamorano, A., Granell, A., and Pallas, V. 2013. A remarkable synergistic effect at the transcriptomic level in peach fruits doubly infected by Prunus necrotic ringspot virus and Peach latent mosaic viroid. Virol. J. 10:164.

Houser-Scott, F., Baer, M. L., Liem, K. F., Jr., Cai, J. M., and Gehrke, L. 1994. Nucleotide sequence and structural determinants of specific binding of coat protein or coat protein peptides to the $3^{\prime}$ untranslated region of alfalfa mosaic virus RNA 4. J. Virol. 68:2194-2205.

Houwing, C. J., and Jaspars, E. M. 2000. Activation of the Alfalfa mosaic virus genome by viral coat protein in non-transgenic plants and protoplasts. The protection model biochemically tested. Arch. Virol. 145:1335.

Huang, Y. W., Hu, C. C., Lin, N. S., and Hsu, Y. H. 2012. Unusual roles of host metabolic enzymes and housekeeping proteins in plant virus replication. Curr. Opin. Virol. 2:676-682.

Ibrahim, A., Hutchens, H. M., Berg, R. H., and Loesch-Fries, L. S. 2012. Alfalfa mosaic virus replicase proteins, $\mathrm{P} 1$ and $\mathrm{P} 2$, localize to the tonoplast in the presence of virus RNA. Virology 433:449-461.

Ifuku, K., Yamamoto, Y., Ono, T. A., Ishihara, S., and Sato, F. 2005. PsbP protein, but not PsbQ protein, is essential for the regulation and stabilization of photosystem II in higher plants. Plant Physiol. 139:11751184.

Ifuku, K., Ishihara, S., Shimamoto, R., Ido, K., and Sato, F. 2008. Structure, function, and evolution of the PsbP protein family in higher plants. Photosynth. Res. 98:427-437.

Ifuku, K., Ishihara, S., and Sato, F. 2010. Molecular functions of oxygenevolving complex family proteins in photosynthetic electron flow. J. Integr. Plant Biol. 52:723-734.

Ishibashi, K., Naito, S., Meshi, T., and Ishikawa, M. 2009. An inhibitory interaction between viral and cellular proteins underlies the resistance of tomato to nonadapted tobamoviruses. Proc. Natl. Acad. Sci. U.S.A. 106:8778-8783.

Ivanov, K. I., and Makinen, K. 2012. Coat proteins, host factors and plant viral replication. Curr. Opin. Virol. 2:712-718.

Jang, C., Seo, E. Y., Nam, J., Bae, H., Gim, Y. G., Kim, H. G., Cho, I. S., Lee, Z. W., Bauchan, G. R., Hammond, J., and Lim, H. S. 2013. Insights into Alternanthera mosaic virus TGB3 functions: Interactions with Nicotiana benthamiana PsbO correlate with chloroplast vesiculation and veinal necrosis caused by TGB3 over-expression. Front. Plant Sci. $4: 5$.

Jaspars, E. M. 1999. Genome activation in alfamo- and ilarviruses. Arch. Virol. 144:843-863.

Jaspars, E. M., and Bos, L. 1980. Alfalfa mosaic virus. CMI/AAB Descr. Plant Viruses No. 229.

Jaspars, E. M., and Houwing, C. J. 2002. A genome-activating N-terminal coat protein peptide of alfalfa mosaic virus is able to activate infection by RNAs 1, 2 and 3 but not by RNAs 1 and 2. Further support for the messenger release hypothesis. Arch. Virol. 147:857-863.

Jimenez, I., Lopez, L., Alamillo, J. M., Valli, A., and Garcia, J. A. 2006 Identification of a Plum pox virus CI-interacting protein from chloroplast that has a negative effect in virus infection. Mol. Plant-Microbe Interact. 19:350-358.
Jin, Y., Ma, D., Dong, J., Li, D., Deng, C., Jin, J., and Wang, T. 2007. The HC-Pro protein of Potato Virus $Y$ interacts with NtMinD of tobacco. Mol. Plant-Microbe Interact. 20:1505-1511.

Jones, R. A. C. 2012. Virus diseases of annual pasture legumes: Incidences, losses, epidemiology, and management. Crop Pasture Sci. 63:399-418.

Kaido, M., Inoue, Y., Takeda, Y., Sugiyama, K., Takeda, A., Mori, M., Tamai, A., Meshi, T., Okuno, T., and Mise, K. 2007. Downregulation of the NbNACal gene encoding a movement-protein-interacting protein reduces cell-to-cell movement of Brome mosaic virus in Nicotiana benthamiana. Mol. Plant-Microbe Interact. 20:671-681.

Kakiuchi, S., Uno, C., Ido, K., Nishimura, T., Noguchi, T., Ifuku, K., and Sato, F. 2012. The PsbQ protein stabilizes the functional binding of the PsbP protein to photosystem II in higher plants. Biochim. Biophys. Acta 1817:1346-1351.

Kong, L., Wu, J., Lu, L., Xu, Y., and Zhou, X. 2014. Interaction between Rice stripe virus disease-specific protein and host PsbP enhances virus symptoms. Mol. Plant 7:691-708.

Krab, I. M., Caldwell, C., Gallie, D. R., and Bol, J. F. 2005. Coat protein enhances translational efficiency of Alfalfa mosaic virus RNAs and interacts with the eIF4G component of initiation factor eIF4F. J. Gen. Virol. 86:1841-1849.

Kumar, A., Reddy, V. S., Yusibov, V., Chipman, P. R., Hata, Y., Fita, I. Fukuyama, K., Rossmann, M. G., Loesch-Fries, L. S., Baker, T. S., and Johnson, J. E. 1997. The structure of alfalfa mosaic virus capsid protein assembled as a $\mathrm{T}=1$ icosahedral particle at 4.0-A resolution. J. Virol 71:7911-7916.

Lehto, K., Tikkanen, M., Hiriart, J. B., Paakkarinen, V., and Aro, E. M. 2003. Depletion of the photosystem II core complex in mature tobacco leaves infected by the Flavum strain of Tobacco mosaic virus. Mol. Plant-Microbe Interact. 16:1135-1144.

Liu, C., and Nelson, R. S. 2013. The cell biology of Tobacco mosaic virus replication and movement. Front. Plant Sci. 4:12.

Loesch-Fries, L. S., Jarvis, N. P., Krahn, K. J., Nelson, S. E., and Hall, T. C. 1985. Expression of alfalfa mosaic virus RNA 4 cDNA transcripts in vitro and in vivo. Virology 146:177-187.

Love, A. J., Geri, C., Laird, J., Carr, C., Yun, B. W., Loake, G. J., Tada, Y., Sadanandom, A., and Milner, J. J. 2012. Cauliflower mosaic virus protein P6 inhibits signaling responses to salicylic acid and regulates innate immunity. PLoS One 7:e47535.

Maciver, S. K., and Hussey, P. J. 2002. The ADF/cofilin family: Actinremodeling proteins. Genome Biol. 3:reviews3007.

Mandadi, K. K., and Scholthof, K. B. 2013. Plant immune responses against viruses: How does a virus cause disease? Plant Cell 25:14891505.

Manfre, A., Glenn, M., Nunez, A., Moreau, R. A., and Dardick, C. 2011. Light quantity and photosystem function mediate host susceptibility to Turnip mosaic virus via a salicylic acid-independent mechanism. Mol. Plant-Microbe Interact. 24:315-327.

Mangeon, A., Junqueira, R. M., and Sachetto-Martins, G. 2010. Functional diversity of the plant glycine-rich proteins superfamily. Plant Signal. Behav. 5:99-104.

Marchot, P., and Chatonnet, A. 2012. Enzymatic activity and protein interactions in alpha/beta hydrolase fold proteins: Moonlighting versus promiscuity. Protein Peptide Lett. 19:132-143.

Mayer, M. P. 2005. Recruitment of Hsp70 chaperones: A crucial part of viral survival strategies. Rev. Physiol. Biochem. Pharmacol. 153:1-46.

Mine, A., and Okuno, T. 2012. Composition of plant virus RNA replicase complexes. Curr. Opin. Virol. 2:669-675

Nagy, P. D., and Pogany, J. 2010. Global genomics and proteomics approaches to identify host factors as targets to induce resistance against Tomato bushy stunt virus. Adv. Virus Res. 76:123-177.

Nagy, P. D., Wang, R. Y., Pogany, J., Hafren, A., and Makinen, K. 2011. Emerging picture of host chaperone and cyclophilin roles in RNA virus replication. Virology 411:374-382.

Neeleman, L., Olsthoorn, R. C., Linthorst, H. J., and Bol, J. F. 2001. Translation of a nonpolyadenylated viral RNA is enhanced by binding of viral coat protein or polyadenylation of the RNA. Proc. Natl. Acad. Sci. U.S.A. 98:14286-14291.

$\mathrm{Ni}$, P., and Kao, C. C. 2013. Non-encapsidation activities of the capsid proteins of positive-strand RNA viruses. Virology 446:123-132.

Nomura, H., Komori, T., Uemura, S., Kanda, Y., Shimotani, K., Nakai, K., Furuichi, T., Takebayashi, K., Sugimoto, T., Sano, S., Suwastika, I.N., Fukusaki, E., Yoshioka, H., Nakahira, Y., and Shiina, T. 2012. Chloroplast-mediated activation of plant immune signalling in Arabidopsis. Nat. Commun. 3:926.

Padmanabhan, M. S., and Dinesh-Kumar, S. P. 2010. All hands on deck-the role of chloroplasts, endoplasmic reticulum, and the nucleus in driving plant innate immunity. Mol. Plant-Microbe Interact. 23:1368-1380.

Pallas, V., Aparicio, F., Herranz, M. C., Amari, K., Sanchez-Pina, M. A., 
Myrta, A., and Sanchez-Navarro, J. A. 2012. Ilarviruses of Prunus spp. A continued concern for fruit trees. Phytopathology 102:1108-1120.

Pena, E., Niehl, A., and Heinlein, M. 2012. Viral studies point the way: Mechanisms of intercellular transport. Short Long Distance Signal. 3:143.

Perez-Bueno, M. L., Rahoutei, J., Sajnani, C., Garcia-Luque, I., and Baron, M. 2004. Proteomic analysis of the oxygen-evolving complex of photosystem II under biotec stress: Studies on Nicotiana benthamiana infected with tobamoviruses. Proteomics 4:418-425.

Perez-Bueno, M. L., Baron, M., and Garcia-Luque, I. 2011. PsbO, PsbP, and PsbQ of photosystem II are encoded by gene families in Nicotiana benthamiana. Structure and functionality of their isoforms. Photosynthetica 49:573-580.

Petrillo, J. E., Rocheleau, G., Kelley-Clarke, B., and Gehrke, L. 2005 Evaluation of the conformational switch model for Alfalfa mosaic virus RNA replication. J. Virol. 79:5743-5751.

Pogany, J., Stork, J., Li, Z., and Nagy, P. D. 2008. In vitro assembly of the Tomato bushy stunt virus replicase requires the host heat shock protein 70. Proc. Natl. Acad. Sci. U.S.A. 105:19956-19961.

Prod'homme, D., Jakubiec, A., Tournier, V., Drugeon, G., and Jupin, I. 2003. Targeting of the Turnip yellow mosaic virus 66K replication protein to the chloroplast envelope is mediated by the $140 \mathrm{~K}$ protein. J. Virol. 77:9124-9135.

Prokhnevsky, A. I., Peremyslov, V. V., Napuli, A. J., and Dolja, V. V. 2002. Interaction between long-distance transport factor and Hsp70-related movement protein of Beet yellows virus. J. Virol. 76:11003-11011.

Qiao, Y., Li, H. F., Wong, S. M., and Fan, Z. F. 2009. Plastocyanin transit peptide interacts with Potato virus $X$ coat protein, while silencing of plastocyanin reduces coat protein accumulation in chloroplasts and symptom severity in host plants. Mol. Plant-Microbe Interact. 22:15231534.

Reichert, V. L., Choi, M., Petrillo, J. E., and Gehrke, L. 2007. Alfalfa mosaic virus coat protein bridges RNA and RNA-dependent RNA polymerase in vitro. Virology 364:214-226.

Reusken, C. B., Neeleman, L., and Bol, J. F. 1994. The 3'-untranslated region of alfalfa mosaic virus RNA 3 contains at least two independent binding sites for viral coat protein. Nucleic Acids Res. 22:13461353.

Rodriguez-Herva, J. J., Gonzalez-Melendi, P., Cuartas-Lanza, R., AntunezLamas, M., Rio-Alvarez, I., Li, Z., Lopez-Torrejon, G., Diaz, I., Del Pozo, J. C., Chakravarthy, S., Collmer, A., Rodriguez-Palenzuela, P., and Lopez-Solanilla, E. 2012. A bacterial cysteine protease effector protein interferes with photosynthesis to suppress plant innate immune responses. Cell Microbiol. 14:669-681.

Rospert, S., Dubaquie, Y., and Gautschi, M. 2002. Nascent-polypeptideassociated complex. Cell. Mol. Life Sci. 59:1632-1639.

Samac, D. A., Nelson, S. E., and Sue Loesch-Fries, L. 1983. Virus protein synthesis in alfalfa mosaic virus infected alfalfa protoplasts. Virology 131:455-462.

Seo, J. K., Hwang, S. H., Kang, S. H., Choi, H. S., Lee, S. H., Sohn, S. H., and Kim, K. H. 2007. Interaction study of Soybean mosaic virus proteins with soybean proteins using the yeast-two hybrid system. Plant Pathol. J. 23:281-286.

Serrano, M., Wang, B., Aryal, B., Garcion, C., Abou-Mansour, E., Heck, S., Geisler, M., Mauch, F., Nawrath, C., and Metraux, J. P. 2013. Export of salicylic acid from the chloroplast requires the multidrug and toxin extrusion-like transporter EDS5. Plant Physiol. 162:1815-1821.

Sharma, P., Jha, A. B., Dubey, R. S., and Pessarakli, M. 2012. Reactive oxygen species, oxidative damage, and antioxidative defense mechanism in plants under stressful conditions. J. Bot. 2012:1-26.

Simon, A. E., and Gehrke, L. 2009. RNA conformational changes in the life cycles of RNA viruses, viroids, and virus-associated RNAs. Biochim. Biophys. Acta 1789:571-583.
Spetea, C. 2012. Role of chloroplast thylakoid lumen in photosynthetic regulation and plant cell signaling. Prog. Bot. 73:207-230.

Spoel, S. H., and Dong, X. 2012. How do plants achieve immunity? Defence without specialized immune cells. Nat. Rev. Immunol. 12:89-100.

Strawn, M. A., Marr, S. K., Inoue, K., Inada, N., Zubieta, C., and Wildermuth, M. C. 2007. Arabidopsis isochorismate synthase functional in pathogen-induced salicylate biosynthesis exhibits properties consistent with a role in diverse stress responses. J. Biol. Chem. 282:59195933.

Su, S., Liu, Z., Chen, C., Zhang, Y., Wang, X., Zhu, L., Miao, L., Wang, X. C., and Yuan, M. 2010. Cucumber mosaic virus movement protein severs actin filaments to increase the plasmodesmal size exclusion limit in tobacco. Plant Cell 22:1373-1387.

Sung, D. Y., Vierling, E., and Guy, C. L. 2001. Comprehensive expression profile analysis of the Arabidopsis Hsp70 gene family. Plant Physiol. 126:789-800.

Sung, T. Y., Chung, T. Y., Hsu, C. P., and Hsieh, M. H. 2011. The ACR11 encodes a novel type of chloroplastic ACT domain repeat protein that is coordinately expressed with GLN2 in Arabidopsis. BMC Plant Biol. 11:118.

Tilsner, J., and Oparka, K. J. 2012. Missing links?-The connection between replication and movement of plant RNA viruses. Curr. Opin. Virol. 2:705-711.

Ueki, S., and Citovsky, V. 2002. The systemic movement of a tobamovirus is inhibited by a cadmium-ion-induced glycine-rich protein. Nat. Cell Biol. 4:478-486.

Uhr, M., Sankbeil, J., and Simpson, D. 2004. Detection of protein: Protein interactions using the MagnetGST pull-down system Promega Notes 87:23-26

van der Heijden, M. W., Carette, J. E., Reinhoud, P. J., Haegi, A., and Bol, J. F. 2001. Alfalfa mosaic virus replicase proteins P1 and P2 interact and colocalize at the vacuolar membrane. J. Virol. 75:1879-1887.

van der Vossen, E. A. G., Neeleman, L., and Bol, J. F. 1994. Early and late functions of alfalfa mosaic virus coat protein can be mutated separately. Virology 202:891-903.

Vinyard, D. J., Ananyev, G. M., and Dismukes, G. C. 2013. Photosystem II: The reaction center of oxygenic photosynthesis. Annu. Rev. Biochem. 82:577-606

Wang, R. Y., Stork, J., and Nagy, P. D. 2009a. A key role for heat shock protein 70 in the localization and insertion of tombusvirus replication proteins to intracellular membranes. J. Virol. 83:3276-3287.

Wang, R. Y., Stork, J., Pogany, J., and Nagy, P. D. 2009b. A temperature sensitive mutant of heat shock protein 70 reveals an essential role during the early steps of tombusvirus replication. Virology 394:28-38.

Wang, X., Goregaoker, S. P., and Culver, J. N. 2009c. Interaction of the Tobacco mosaic virus replicase protein with a NAC domain transcription factor is associated with the suppression of systemic host defenses. J. Virol. 83:9720-9730.

Wegrzyn, R. D., Hofmann, D., Merz, F., Nikolay, R., Rauch, T., Graf, C., and Deuerling, E. 2006. A conserved motif is prerequisite for the interaction of NAC with ribosomal protein L23 and nascent chains. J. Biol. Chem. 281:2847-2857.

Willows, S., Hou, S. M., and Hobman, T. C. 2013. RNA virus capsid proteins: More than just a shell. Future Virol. 8:435-450.

Zvereva, A. S., and Pooggin, M. M. 2012. Silencing and innate immunity in plant defense against viral and non-viral pathogens. Viruses 4:25782597.

\section{AUTHOR-RECOMMENDED INTERNET RESOURCES}

NCBI BLAST database: www.ncbi.nlm.nih.gov/BLAST

The Arabidopsis Information Resource Center: www.arabidopsis.org 